\title{
Are Disaggregate Industrial Returns Sensitive to Economic Policy Uncertainty
}

\author{
MOBEEN UR REHMAN \\ Corresponding Author(Mobeen@tdtu.edu.vn) \\ Informetrics Research Group, Ton Duc Thang University, Ho Chi Minh City, Vietnam \\ Faculty of Social Sciences and Humanities, Ton Duc Thang University, Ho Chi Minh City, \\ Vietnam \\ NADIA ASGHAR \\ University of Wolverhampton, Wolverhampton, $U K$
}

JAVED HUSSAIN

Birmingham City University, Birmingham, UK

\begin{abstract}
This study investigates the impact of economic policy uncertainty on disaggregate US sector based returns. Our work is motivated by the presence of non-linear relationship between US economic policy uncertainty and equity returns of sampled US sectors. The paper uses weekly data from January 1995 to December 2015 for all the return indices and economic policy uncertainty data mainly based on policy issues, provision set for the US federal tax code and disagreement among economic forecasters. Our results indicate that information technology, utilities, industrial and telecommunication sectors remain insensitive to changes in the US economic policy uncertainty. However, financial and the consumer discretionary sectors show significant long run asymmetric relationship with the EPU.
\end{abstract}

Keywords: Economic policy uncertainty; NARDL; Sectoral returns 


\section{Introduction}

Series of global financial crises in $21^{\text {st }}$ century, steep economic decline and slow recoveries have intensified the concern of regulatory bodies for economic policy uncertainty (Bloom, 2009; Pastor \& Veronesi, 2013; Baker, Bloom \& Davis, 2016). Post crisis sluggish recovery and decrease in economic activity is also attributed as the repercussions of uncertainty in fiscal, monetary, economic and regulatory policies (Christou et al., 2017). Policy makers are driven by variety of social, economic and political factors when developing economic policies, however, investors are unable to anticipate the impact of these factors on policy outcome and ultimately on firm value (Nagar et al., 2018). Working environment of economy and private sector is subject to the government economic policies, however, uncertainty in policies can elicit strong reaction from financial markets (Chen et al., 2017). Economic Policy uncertainty (EPU) refers towards uncertainty contributed by the government policy makers to fiscal, monetary and regulatory policies, uncertain electoral outcomes or uncertain tax regimes (Baker et al., 2016; Yu et al., 2018). Uncertainty from policy makers escalates risk premium, causes delays in individual and business spending until such uncertainty is resolved (Brogaard \& Detzel, 2015). Strong and credible policy framework has a favourable influence on the economy and act as an impulse behind stable macroeconomic performance (Arbatli et al., 2017). Economists have therefore, concluded EPU as an important factor due to its substantial impact on economic activity during recession periods, though weak impact on economic activity is observed in the subsequent revival periods (Baker et al., 2016). From an economic agent's point of view, economic policy defines parameter for decision with high uncertainty delaying the decision-making process and ultimately the economic activity (Arouri et al., 2014).

EPU represents economic risk for a country due to an uncertain path of government policy, therefore, a credible and stable economic policy have favourable impact on the economy of the country (Arbatli et al., 2017). Reaction to changes in economic policies is weak if these are easy to predict; however, reaction can be strong if market is caught by uncertainty in economic policies (Pastor\& Veronesi, 2012). Existing literature documents negative affect of uncertainty in polices on economic growth with probable effects on the macroeconomic variables (See Bloom et al., 2007; Pastor\& Veronesi, 2013; Gulen \& Ion, 2015; Christou et al., 2017). High uncertainty not only provide grounds for firms to delay their investment decision and increase 
unemployment in the economy (Bernanke, 1983; Bachmann et al., 2013; Scotti, 2016) but also result in cutback on precautionary spending (Pastor \& Veronesi, 2012; Leduc \& Liu, 2016). EPU is therefore aggressively observed for its influence on country level (Brogaard \& Detzel, 2015; Baker et al., 2016), financial markets (Antonakakis, 2013), industries (Gulen \& Ion, 2015) and at equity pricing level (Yu et al., 2018).

International capital markets remain an important topic of discussion not only for academic research but also for portfolio managers and policy makers (Jones et al., 1996; Rapach \& Zhou, 2013; Antonakakis et al., 2017). Due to its significance, EPU is rigorously studied for its impact on stock market returns though some studies suggest negative effect of EPU on stock returns (Antonakakis et al., 2013; Kang \& Ratti, 2013; Chen et al., 2016). In some cross-country analysis, it is also observed that stock returns of a market significantly respond specifically to its own EPU (See Sum, 2013; Momin, \& Masih, 2015; Li et al., 2016). Furthermore, investigating EPU in developed markets i.e. US also conclude its dynamic impact on international equity market returns with respect to portfolio diversification (Mensi et al., 2014; Balcilar et al., 2015).

There is a mounting literature investigating the influence of economic policy uncertainty on fiscal, financial, regulatory, economics and microeconomic fundamentals (Phan et al., 2018; Rehman, 2018; Beckmann \& Czudai, 2016; Brogaard \& Detzel, 2015; Jones \& Oslon, 2013; Aastveit et al., 2013). On the other end, another strand of literature demonstrates significant impact of economic policy uncertainty on the performance of global stock markets (Chen et al., 2017; Christou et al., 2017; Tsai, 2017; Li et al., 2016; Gao \& Zhang, 2016). However, limited studies analyze the impact of economic policy uncertainty on sectoral returns (Yu et al., 2018; Boutchkova et al., 2011) and therefore our work derives its motivation from an empirical contribution of Yu et al (2018), Yu et al (2017), Donadelli and Persha (2014) on the US market. Their results highlight significant impact of EPU on sectoral returns of US stock market. However, their results focus only on the long-run relationship between sectoral returns and economic policy uncertainty. There is a strand of literature discussing the non-linear relationship of equity returns to macroeconomic variables (Rehman et al., 2018; Uddin et al., 2018; Shahzad et al., 2018), however sensitivity of sectoral equity returns to economic policy uncertainty shocks under non-linear framework remained untapped. Therefore, our work also adds to the existing literature by analyzing non-linear relationship to measure asymmetries between economic policy 
uncertainty and sectoral returns. Only few studies (see for example Shahzad et al. 2018) analyze the relationship between EPU and global stock returns, however our study studies non-linear relationship at sectoral level returns.

In this paper, we contribute towards the existing literature in following ways. First, we investigate the non-linear impact of economic policy uncertainty on US equity market returns, to our best knowledge it is the first attempt to analyse the impact of EPU on disaggregate industrial returns. To measure asymmetric relationship, we decompose EPU into positive and negative components. Second, we test the sensitivity of US equity market to EPU in the form of major sectoral returns to measure the sensitivity of each sector to economic policy uncertainty. By doing this our study becomes more useful for investors having portfolio among different sectors to achieve optimal diversification benefits. Third, our study contributes in providing the short and long run asymmetric relationships between different sectoral returns and US EPU. These results can be helpful for both short and long run investors in the US equity market. Fourth, the study also entails implications for policy makers and the investment community to have an insight on the sensitivity of US equity markets behaviour attributable to economic policy uncertainty. This study also highlights the industries unrelated to EPU in the selected sample, which further add value to the investment decisions of those investors who are risk averse and reluctant to take position during the periods of high economic uncertainties.

Results of our study highlight that utilities, information technology, telecommunication and industrial sectors remains insensitive to changes in the US economic policy uncertainty. However, when analysing the short run and long run relationship in an asymmetric and symmetric framework, we report co-integrating relationship between EPU and the healthcare, financials and materials sector returns. Among other sectors, financial and the consumers sectors show significant long run asymmetric relationship. For both short and long-run asymmetric relationship of EPU with equity returns, significant co-integrating relationship between EPU and returns of consumer discretionary, financials, materials and automobiles sectors are witnessed.

Rest of the paper is structured as follows. Section 2 presents review of past literature. Section 3 list data sources and further explain the methodological framework. Section 4 presents analysis followed by section 5 presenting conclusion. 


\section{Literature Review}

Though recent literature documents discussion on the impact of economic policy uncertainty (thereafter EPU) on economic agents and their performance particularly after 200709 global financial crises (Antonakakis et al., 2013), howev er, its origin is more than 30 years old (see, Marcus, 1981; Bernanke, 1983; Rodrik, 1991; Bloom, 2007). Rodrik (1991) is among the pioneers who witnessed uncertainty as a root cause of delay for investment decisions in developing countries. A strand of literature also presents findings on the detrimental economic effect of fiscal, monetary and regulatory policy uncertainty (Higgs, 1997; Hassett \& Metcalf, 1999). EPU has remained an area of interest for economists as well as the policy makers, which is evident from the rich literature discussing impact of policy uncertainty on macroeconomic variables (see Ali, 2001; Baum et al., 2009; Jones \& Oslon, 2013). In recent literature, policy uncertainty is investigated for its impact on household saving, (Giavazzi \& McMahon, 2012), stock market volatility (Pastor \& Veronesi, 2013), delay in firm's entry (Handley \& Limao, 2015) and asset returns (Brogaard \& Detzel, 2015). Similarly, Arbatli et al. (2017) reported negative effect of EPU on employment, output (capital goods), consumption and investments.

Arguably, it is observed that investors postpone their equity investment decisions during period of high uncertainty as policy uncertainty increases cost of capital (Pastor and Veronesi, 2012). Gulen and Ion (2015) provides empirical evidence that due to such uncertainties, investment decisions become more risker and expensive, which ultimately decreases liquidity and US stock market returns. Fang et al. (2017) observed negative correlation between US bonds and stock returns during high economic policy uncertainty periods and conclude that during periods of policy uncertainty demand for bonds is higher than stocks as investor substitute safe assets to the risky ones in their portfolio. Kang et al. (2014) report that investment decisions at firm's level are delayed or depressed when EPU is coupled with firm level uncertainty. Economic policy uncertainty has significant negative impact not only on the financial and economic activities but also influence business cycle and investment decisions (Bloom, 2009 \& Baker et al, 2016). Apart from the impact of EPU on traditional investment market (Bekiros et al, 2016), effect of EPU is also influential on gold returns (Balcilar et al., 2016), economic activity (Fernandez et al., 2013) and oil and gas returns. (Kang et al, 2017). 
Existing literature has consensus on significant negative effect of EPU on stock market returns. Brogaard and Detzel (2015) capture the effect of EPU on equity returns and volatility of 21 countries and conclude that EPU has negative impact on stock returns, however positive impact on stock market volatility. Chang et al. (2015) investigate OECD countries and report negative impact of EPU on US and UK equity market pricing. Effects of US economic policy uncertainty are not limited to its own financial markets as Lean and Nguyen (2014) conclude that EPU of US during the global crisis period affected Dow Jones sustainability indices for the Asia Pacific and North American regions. Besides developed markets, developing and emerging markets entail mixed results. Using quantile regression approach Mensi et al. (2014) report that economic policy uncertainty does not affect BRICS stock market returns, however Dakhlaoui and Aloui (2016) report different results by sharing time varying correlation between BRIC stock market volatility and US economic policy uncertainty. Arouri et al. (2014) examine US, Europe, China and the Gulf equity markets and find negative effect of economic policy uncertainty on stock market returns. Using a non-parametric causality in quantile methodology, Antonakakis et al. (2016) highlight that US economic policy uncertainty indicators have power to predict the US sustainable investment index.

There are few studies that discuss relationship between economic policy uncertainty and sectoral returns. For example, Kang et al. (2017) explore the relationship between economic policy uncertainty and returns in oil and gas sector using structural VAR with negative effect of EPU on stock returns. In another study using nonparametric granger causality test, Bekiros et al. (2016) investigates the role of EPU and firm level uncertainty to predict movements in stock returns and volatility. Similarly, Antonakakis et al. (2013) witness consistent negative co-movement among stock returns, volatility and EPU for US market using DCC-GARCH model. Their results are similar to the conclusions drawn by Kang and Ratti (2013) using VAR framework. Arouri and Roubaud (2016) report that increasing value of economic policy uncertainty increase market volatility whereas decreases stock market returns. Baker et al. (2016) use firm level data of 12 major economies and conclude that EPU not only affects stock price volatility but also negatively influence investments as well as employment in the construction, defense and healthcare sectors. 
Effects of EPU are not limited to global and international equity returns and they are also significant at the sectoral level. According to Boutchkova et al. (2011) and Baker et al. (2016), labor intensive industries are more sensitive to the decisions driven by EPU compared to other industries. While analyzing the impact of economic policy uncertainty on industrial returns, Badshah et al. (2018) report positive effect on energy commodities and industrial metals, whereas negative effect on precious metals. Hoque and Zaidi (2018) also highlight non-linear, non-monotonic and asymmetric relationship between sectoral returns and EPU. They conclude that because EPU predict stock returns, it can be included as a proxy of systematic risk in asset pricing and investment decisions. Similarly, Yu et al (2017) analyze long-run impact of EPU on ten US industries with the findings that EPU significantly drives industry beta. They find that technology, financial and material sectors are more sensitive to changes in EPU compared to consumer staples, energy and utilities sector. Yu et al. (2018) investigate the effect of EPU on US Industry level data to examine long-run volatilities and observe that EPU causes a decrease in long-run volatilities of consumer staple, healthcare, information technology and materials however, increases long-run volatility of industrial and material sectors.

Literature on predictive power of EPU on sectoral return is very thin, however, few notable contributions on sectoral returns re on testing the impact of global EPU. Like Yu et al. (2018) analyze the effect of global EPU on the volatility and correlation pattern between US sectoral returns and crude oil market, they observed that EPU have positive impact on the long run correlation between US sectoral returns and oil prices. Similarly, while investigating the impact of global EPU on long run volatility and correlation in crude oil and industry level stock returns of US market, Yu et al. (2018) reported that financials and consumer discretionary are positively related to GEPU. Information Technology, Energy, Material and Telecommunication services exhibited negative relationship, while other industries like, Health care, Utilities, Industrials and consumer staples showed significant link with GEPU. Above mentioned studies not only provide the motivation to conduct the empirical analysis on industry level data but also driven the researcher to test whether results vary if GEPU is replaced by US EPU. 
Prior literature entails different methodologies ${ }^{1}$ in examining the effects of EPU on stock returns at firm, industry and market level data. Among GARCH family models, Donadelli and Persha (2014) and Antonakakis et al. (2013) utilize DCC-GARCH framework. Later, Lean and Nguyen (2014) and Dakhlaoui and Aloui (2016) use GARCH, IGARCH, EGARCH \& TGARCH family models. Among otherstudies, Adjei and Adjei (2017) examine the predictive power of EPU by employing multivariate GARCH model in testing the relationship between EPU and equity market returns. Among other multivariate techniques, Christou et al. (2017) and Kang \& Ratti (2013) apply panel VAR model, Li et al. (2016) and Wu et al. (2016) use bootstrap full sample Granger causality and sub-sampling rolling window estimation, Arouri et al. (2014), use correlation and panel regression whereas Yu et al. (2017) test DCC-MIDAS. Existing literature documents that it is not necessary that the stock returns always fall at the news of policy change; result may vary over the selected samples and therefore, researcher should also explore the asymmetric relationship of EPU with stock returns across industries (Wu et al., 2016) both in short and long run. The application of all the above linear estimation techniques and given prior evidence of non-linear relationship between economic policy uncertainty and stock returns, we apply non-linear auto regressive distributed lag model framework in capturing the short- and long-run dynamics

\section{Data and Methodology}

\section{a) Data and preliminary analysis}

Data on EPU is based on three main components: the newspaper coverage of economic uncertainty in relevance to policy issues, the provision set for the federal tax code for future years, and the disagreement across economic forecasters. Weekly data for US EPU is sourced from http://www.policyuncertainty.com/. Daily equity pricing data for nine major US sectors is obtained from Data Stream, which is then converted into weekly average returns. These sectors include healthcare, consumer discretionary, financials, industrials, telecommunication, materials, information technology, utilities and automobiles. Period of our data is therefore ranges from 1995-2015 with analysis based on weekly data frequency. Detailed information on sectors with their market capitalization and number of listed companies is provided in Table 1. Figure 1

\footnotetext{
${ }^{1}$ Please refer Table A1 in appendix
} 
presents S\&P 500 sector weightings $^{2}$ from 1990 to 2016 and it is evident that all the industries represent significant market capitalization of the aggregate S\&P 500 index. IT sector remains at top position with significant spikes in early 2000' following a steady pattern thereafter, however, Utilities and telecommunication sector is consistently at a lowest position. Figure 2 presents time trend of the sampled sectors in which all the sectors experiences significant downfall in returns attributable to the global financial crisis of 2008-09, however this drop in sectoral returns is more observed for the US financial sectors and least for the healthcare and telecommunications sector. Table 2 provides descriptive statistics of US sectors-based return on weekly basis and economic policy uncertainty. Telecommunication and automobile sectors have lowest mean values whereas healthcare and information technology have the highest monthly returns of 0.02 percent. Information technology, financials and automobile sectors show higher variance in returns in comparison to rest of the sectors in the study. Except EPU, all sectoral returns exhibit negative skewness with fat tails. Value of kurtosis highlights presence of leptokurtic distribution in all the series however serial correlation is also witnessed in most of the series.

Broock Dechert Scheinkam (BDS) test by Broock et al. (1996) is used as a diagnostic test to check the presence of non-linearity in data set before the application of any nonlinear framework on the data. The BDS test as a diagnostic present itself as a test of independence applied to estimated residuals of a time series or a model driven by independent and identically distributed error terms. The first order asymptotic distribution of the BDS test is independent of estimation errors under the assumption that the model parameters are consistently estimated. Due to this reason, the BDS test provides itself as an effective specification test and a diagnostic tool. Results of BDS test are presented in Table 3 clearly rejects the existence of any linear structure in the residuals of economic policy uncertainty and US sectoral returns framework.

We further apply non-linear granger causality test of Diks and Panchenko (2006) as a diagnostic check to test linearity in our model between sectoral returns and economic policy uncertainty (see Table 4). We used embedding dimensions at $\mathrm{m}=2,3,4$ for robustness against the lag order and witness anonymous results for all embedding dimensions. Our results do not reject the null hypothesis of no non-linear granger causality suggesting the application of non-parametric estimations. The rejection of null hypothesis on the presence of independent and individual

\footnotetext{
${ }^{2}$ Source: http://siblisresearch.com/data/sp-500-sector-weightings/
} 
distribution and no non-linearity are rejected and therefore, allows the application of the nonlinear auto regressive distributed lag (ARDL) framework, details of which along with the rational of application is discussed in next sub-section.

\section{b) Methodological Approach}

To account for any non-linear structure between economic policy uncertainty and US disaggregated sector returns, this study has applied non-linear auto regressive distributed lag framework proposed by Shin et al. (2014). This model is an extension of the traditional error correction model (ECM) proposed by Engle and Granger (1987) however with a limitation of measuring short and long run asymmetric behaviors.

The application of non-linear autoregressive distributed lag models (NARDL) introduced by Shin et al. (2014) allows for modelling cointegration and asymmetries among underlying variables in a multivariate model. The results of this estimation are more robust compared to standard cointegration approaches i.e. Johansen cointegration and Engle-Granger tests. The NARDL presents itself as an asymmetric expansion of the linear autoregressive distributed lag model (ARDL) proposed by Pesaran et al. (2001). This approach consists of dynamic error correction mechanism that allows for measuring non-linearity in a single equation. This approach also performs better in small samples contrary to conventional cointegration approaches (Romilly et al. 2001). According to Nusair (2016), NARDL model also offers more flexibility by providing results irrespective of the level of cointegration i.e. either $I(0), I(1)$ or a combination of both levels. Furthermore, the NARDL method allows testing of hidden cointegration, thereby avoiding omission of any significant relationships not detectable otherwise under the conventional linear models. Therefore, NARDL model allows in distinguishing between linear cointegration, non-linear cointegration and no cointegration. A representation of the conventional autoregressive distributed lag model (ARDL) is appended below.

$$
\Delta r e t_{t}=\mu+\rho_{r e t} r e t_{t-1}+\rho_{E P U} E P U_{t-1}+\sum_{i=1}^{p-1} \alpha_{i} \Delta r e t_{t-1}+\sum_{i=0}^{q-1} \beta_{i} \Delta E P U_{t-1}+\varepsilon_{t}
$$

$\triangle E P U_{t}$ in the above equation refers to the US economic policy uncertainty and $r e t_{t-1}$ presents sector returns for US market. The symbol delta $(\Delta)$ denotes values at first differences and $p$ and $q$ represent lag order values for sector returns and economic policy uncertainty. The above 
appended model however, has limitations in estimating asymmetries and non-linearities in price transmission mechanism. Therefore, an extension of the above model proposed by Shin et al. (2014) is used in this study to account for such non-linearities and asymmetries between economic policy uncertainty and equity returns. This Non-linear Auto Regressive Distributed Lags (NARDL) framework is helpful for analyzing non-linear and asymmetric relationships by decomposing independent variables into partial sum process for decreases as well as increases. The expression for such decomposition is presented below.

$$
\begin{aligned}
& E P U_{t}^{+}=\sum_{j=1}^{t} \Delta E P U_{j}^{+}=\sum_{j=1}^{t} \max \left(\Delta E P U_{j}, 0\right) \\
& E P U_{t}^{-}=\sum_{j=1}^{t} \Delta E P U_{j}^{-}=\sum_{j=1}^{t} \min \left(\Delta E P U_{j}, 0\right)
\end{aligned}
$$

As an extension of the traditional ARDL model by Pesaran and Shin (1998) and Pesaran et al. (2001), equations (2) and (3) are used to present more generalized co-integration methodology incorporating both short and long run dynamics as;

$$
\begin{aligned}
& \Delta \text { ret }_{t}=\mu+\rho_{\text {ret }} \text { ret }_{t-1}+\rho_{E P U^{+}} E P U_{t-1}+\rho_{E P U^{-}} E P U_{t-1}+\sum_{i=1}^{p-1} \alpha_{i} \Delta \operatorname{ret}_{t-1}+ \\
& \sum_{i=0}^{q-1}\left(\beta_{i}^{+} \Delta E P U_{t-1}+\beta_{i}^{-} \Delta E P U_{t-1}\right)+\varepsilon_{t}
\end{aligned}
$$

The subscripts (+) and (-) presented in equation (4) are positive and negative partial sum decompositions of values at different lags and first differences of economic policy uncertainty, respectively. Akaike Information Criteria (AIC) is used for selecting the optimal lag lengths of $p$ and $q$. The coefficients $\beta_{i}{ }^{+}$and $\beta_{i}^{-}$capture short run adjustments of US sectoral returns attributable to changes in economic policy uncertainty.

To test the presence of any long run co-integrating relationship between US sector returns, $E P U_{t}{ }^{+}$and $E P U_{t}{ }^{-}$, study follows the Banerjee et al. (1998) methodology by testing $\rho_{\text {ret }}=0$, against $\rho_{\text {ret }}<0$ in equation (4). After this the pragmatic bound testing method proposed by Pesaran et al. (2001) is applied as $F$ test under the joint null hypothesis of $\rho_{\text {ret }}=\rho_{E P U}{ }^{+}=$ $\rho_{E P U}{ }^{-}=0$. This methodology has an advantage of being valid irrespective of the integration level of regressors, i.e. at $I(0), I(1)$ or mutual co-integration, this study use the terms $t_{B D M}$ and 
FPSS respectively for these two tests. The critical value for both these tests depends on the number of regressors, $k$. For long run asymmetries, where long-run relationship is determined by $r e t_{t}, E P U_{t}^{+}$and $E P U_{t}^{-}, k$ ranges between 1 and 2 for more conservative tests.

After testing for long run relationship between economic policy uncertainty and US sector-based returns, potential asymmetric effects need to be tested in case if long-run relationship holds between the two variables. This procedure helps in checking the robustness of hypothesis testing and estimation results to avoid any misspecifications. Wald test is used to test the presence of short run asymmetries with a null hypothesis $H_{o}: \sum_{i=0}^{q-1} \beta_{i}^{+}=\sum_{i=0}^{q-1} \beta_{i}^{-}$, for $\mathrm{i}=0,1, \ldots \mathrm{q}-1$. The presence of long-run asymmetries are also tested through the Wald test under the null hypothesis of $\theta^{+}$and $\theta^{-}$, where $\theta^{+}=-\frac{\rho_{E P U}^{+}}{\rho_{\text {ret }}}$ and $\theta^{-}=-\frac{\rho_{E P U}^{-}}{\rho_{\text {ret }}}$ equation (4) is transformed into the baseline traditional model (1) in case of not rejecting the null of above mentioned two hypotheses thus implying the absence of non- asymmetric relationship between the variables. In case of rejecting only long and short run symmetry, model is reduced to co-integrating NARDL with long or long-run asymmetries, respectively. The resulting equations are appended below.

$$
\begin{aligned}
& \Delta r e t_{t}=\mu+\rho_{r e t} \text { ret }_{t-1}+\rho_{E P U} E P U_{t-1}+\sum_{i=1}^{p-1} \alpha_{i} \Delta \operatorname{ret}_{t-1}+\sum_{i=1}^{q-1}\left(\beta_{i}^{+} \Delta E P U_{t-1}+\right. \\
& \beta_{i}^{-} \Delta E P U_{t-1}+\varepsilon_{t} \\
& \Delta r e t_{t}=\mu+\rho_{r e t} r e t_{t-1}+\rho_{E P U}^{+} E P U_{t-1}+\rho_{E P U}^{-} E P U_{t-1}+\sum_{i=1}^{p-1} \alpha_{i} \Delta r e t_{t-1}+ \\
& \sum_{i=1}^{q-1} \beta_{i} \Delta E P U_{t-1}+\varepsilon_{t}
\end{aligned}
$$

In equations (5) and (6), $\Delta r e t_{t}$ represents sectoral returns as dependent variables along with the one period lag pricing and economic policy uncertainty values as regressors. Equation (5) presents short-run whereas equation (6) present long-run asymmetric dynamics.

\section{Analysis and discussion}

To begin with, we report the bound testing critical values for co-integration between our sampled variables i.e. economic policy uncertainty and US weekly sectoral returns at different confidence intervals, number of variables and integration level (either 0 or 1) in Table 5. Relationship between EPU and sectoral returns of different of sectors with relevance to the specification models i.e. symmetric, short run and long run symmetry, long run asymmetry and 
short run asymmetry are reported from Tables 6-14. The presence of co-integration between economic policy uncertainty and different sector returns is reported through $t_{B D M}$ and FPSS values. FPSS represents $F$ statistics proposed by Pesaran et al. (2001) whereas $t_{B D M}$ represents $t$ statistics proposed by Banerjee et al. (1998). Both these test statistics are used for testing the null hypothesis of no cointegration under the ARDL specification, regardless of the integration order of underlying regressors, i.e. $I(0), I(I)$ or both. Among others, utilities, information technology, telecommunication and industrial sectors remain completely insensitive to any changes in economic policy uncertainty for either symmetric or asymmetric framework in both short and long-run. This conclusion is based on the $t_{B D M}$ and $F_{P S S}$ values that lead to the failure of rejecting the null of no co-cointegration. Similarly, neither of sectors exhibits any symmetrical relationship with economic policy uncertainty. When short run asymmetric relationships are considered, we find co-integrating relationship between EPU and healthcare, financials and materials weekly return values. Financial and consumer discretionary are the only sectors with significant long run asymmetric relationship with EPU however for other sectors no solid inferences can be drawn at either 5 or 10 percent significance level. Finally, considering both, the short and long-run asymmetric relationship between EPU and sectoral returns, we find significant co-integrating relationship of EPU with returns of consumer discretionary, financials, materials and automobiles sectors. However, for remaining sectors, the null hypothesis of no co-integration cannot be rejected at either of the significance level.

The values of Wald test in Table 6 for automobile sector returns suggest the presence of both short and long run asymmetric relationship between economic policy uncertainty and weekly return values. Moving towards the long run coefficients, an increase of 1 percent in EPU causes automobile weekly return values to increase by 2.59 percent whereas a decrease of similar magnitude in EPU decreases returns by 15.72 percent in the long run. In the short run, 12.48 percent increase in returns value is observed due to 1 percent increase in US economic policy uncertainty. Table 7 presents Wald statistics for consumer discretionary sector returns present asymmetric pattern between the relationship of weekly return values and US economic policy uncertainty. There exists a statistically long run robust relationship between weekly returns and economic policy uncertainty as the null hypothesis for no co-integration is rejected across all model specifications i.e. SR and LR symmetry, LR asymmetry and SR asymmetry suggesting the presence of significant co-integrating relationship. The presence of short and 
long run asymmetric relationship further leads towards an investigation of the magnitude of response from consumer discretionary sector returns as a result of the economic policy uncertainty. For this purpose, we accumulate the short and long run asymmetric response of return values also appearing as significant at 5 percent level. Results suggest that in the long run, 1 percent increase in EPU leads to an increase of 4.79 returns however a decrease of similar magnitude in EPU decreases returns by 14 percent. Yu et al. (2018) examined consumer discretionary relation with GEPU and also reported positive effect of GEPU on long run returns and volatility of stock returns. Results for other sectors in this study, however, cannot explain strong inferences at either $5 \%$ or $10 \%$ level of significance. This asymmetric long run relationship can become informative for investors interested in consumer discretionary sector during an economically turbulent condition. In the short run, 1 percent increase in EPU decreases returns by 3.38 percent thereby having implications for short run investors. Table 8 present results of healthcare sector following asymmetric returns pattern where Wald test results suggest the presence of short run asymmetric relationship between EPU and healthcare weekly returns. Change in the value of EPU by 1 percent in long run causes increase in healthcare sector returns by 14.94 percent however short run relationship follows asymmetric pattern, contrary to the findings of Yu et al. (2018) concluding that EPU decreases long run volatility of healthcare returns. In short run, 1 percent decrease in EPU values causes weekly return to decline by 17.37 percent. Rest of the sampled sectors include information technology, utilities, material, telecom, industrials and financials where returns for all these sectors follow short run symmetric and long run asymmetric relationship. Wald test for all these sectors reject the null of no long and short run asymmetric relationship with economic policy uncertainty. These finding on Financials, Industrial, Telecom sectors, confirm the results of Phan et al., (2018) who reported the asymmetric predictability of EPU on excess returns in six out of ten US industries. Similarly, Arouri et al. (2016) also reported the nonlinear relationship of US equity market with EPU however the effect of EPU on equity returns is robust and persistent only under extreme volatilities. Tables 8-13 report complete statistics for short and long run relationship between economic policy uncertainty and weekly sectoral returns over the sampled period for all four specifications i.e. symmetric, short run and long run symmetry, long run asymmetry and short run asymmetry. Wald test results for information technology, utilities, material, telecom, industrials and financials suggest the presence of long 
run asymmetric relationship between US economic policy uncertainty and weekly information technology sector returns however null hypothesis of short run symmetry is rejected. We report statistics of these sectors as follows.

- Table 9 illustrates relationship between US economic policy uncertainty and weekly information technology sector returns. An increase of 1 percent in EPU decreases returns of information technology sector by 39.60 percent in long run and 0.42 percent in the short run however in the long run, a decrease of 1 percent causes an increase of 69 percent. These results suggest that the technology sector is most sensitive to economic policy uncertainty and that investors in both short- and long-run should consider the economic conditions while investing in this sector. These results are also supported by the findings of Fang and Sun (2018) also suggesting an inverse relationship between economic policy uncertainty and information technology sector.

- In Table 10, utilities sector also exhibit sensitivity to changes in EPU as 1 percent increase in EPU increases weekly sectoral returns by 10.90 percent and a decrease of similar magnitude results in an increase of 4.10 percent in the long run. In short run, 0.0127 increase in weekly returns results from a 1 percent increase in US economic policy uncertainty.

- Table 11 present findings for material sector returns exhibiting long run asymmetric relationship with EPU with 1 percent increase in EPU leading to an increase of 11.51 percent weekly returns and an equal decrease in EPU again causes an increase of 7.04 percent. Short run symmetric relationship however highlights that 1 percent change in EPU decreases weekly returns by 0.044 percent.

- For, telecommunication sector, we report results in Table 12 where one percent increase in EPU causes an increase of 28.53 percent whereas a decrease of same magnitude declines weekly stock returns by 5.91 percent in the long run. However, short run symmetry suggests that 1 percent change in EPU changes weekly returns of telecom sector by 0.43 percent.

- Industrials sector remains quite responsive to the EPU asymmetrically in the long run where 1 percent increase in EPU leads an increase of 16.58 percent whereas a decrease of 1 percent decreases weekly equity returns values by 3.06 percent (see Table 13). Phan et al., (2018) also concluded that excess industrial sector retunrs are predictable by changes in 
EPU, however, magnitude of negative EPU shocks are more than the positive shocks. We observe short run symmetric sensitivity of weekly return values to EPU as 1 percent change reduces weekly returns by 6.02 percent in the short run.

- Finally, Wald statistics in Table 14 for financial sector suggest the presence of long run asymmetric and short run symmetric relationship between EPU and stock return values. An increase of 1 percent in the EPU causes an increase of 9.41 percent and a decrease of 1 percent increasing returns by 16.31 percent, both in the long run. Phan et al., (2018) also confirmed an asymmetric predictability of EPU for financial sector, however, positive EPU shock have more impact on returns than the negative shocks. These results also support the finding of Baker et al. (2016), where Financial sector was observed especially responsive to the change in EPU.

The results of short and long-run asymmetric relationship between industry returns and economic policy uncertainty are complemented with the dynamic multipliers findings. The results are in accordance with the statistics presented above highlighting mixed evidences of both short and long run asymmetric structural evidences. All the disintegrated sectoral returns appear quite sensitive to changes in the US economic policy uncertainty, where in most of the cases asymmetric framework in either short run or in the long run are observed. Among all the sectors, significant co-integrating relationship of EPU with consumer discretionary, financials, materials and automobiles sector returns are witnessed. However, returns for remaining sectors also show responsiveness to the economic policy uncertainty. We can see that the Figure 3 highlight adjustment pattern in achieving new equilibrium position attributable to negative or positive EPU shock. The continuous black line represents positive whereas dashed black line represents negative changes capturing adjustment of positive and negative EPU shocks under a specific forecasting horizon, respectively. The broken red line indicates asymmetry reflecting the difference between dynamic multipliers due to positive and negative EPU shocks. This curve is displayed along its upper and lower bounds at 95\% confidence interval. The asymmetric effect of EPU tends to be insignificant at 5\% if the zero line is located between upper and lower bounds. Figure 3 also depicts the adjustment pattern of sectoral returns to positive and negative unitary EPU shocks across both short- and long-run periods. Healthcare, utilities and telecom sectors have direct relationship with unitary EPU shocks whereas remaining sectors exhibit inverse relationship in both short- and long-run periods. Furthermore, 
we witness dominance of positive EPU shocks in consumer discretionary and utilities sector whereas negative shocks in industrials and financial sectors. We also see that effects of EPU shocks, either negative or positive, remains dominant in short run with long-run equilibrium position achieved after 20th week in most of the cases

\section{Conclusion}

We investigate the impact of US economic policy uncertainty on weekly US sectoral stock returns over in short and long run symmetric and asymmetric framework. Sampled sectors consist of automobiles, healthcare, consumer discretionary, financials, industrials, telecommunication, materials, information technology and utilities. Short run cointegration with asymmetric relationship of EPU is observed with the healthcare, financials and materials sector weekly returns whereas both short and long run asymmetric relationship is witnessed for the consumer discretionary, financials, materials and automobiles sectors. We report no co-cointegration of EPU with the utilities, information technology, telecommunication and industrial sectors. Financial and consumer discretionary are the only two sectors with significant long run asymmetric relationship with EPU.

These findings are useful for practitioners, researcher and policy makers to understand the implication of decisions by economic policy makers and investors. Policy makers can contribute in reducing uncertainty and potential risk in the stock market attributable to high price volatility by decreasing delay in their consensus on frequent change in economic policies. Apart from considering fundamentals and technical aspect of investments, investor should consider the change and impact of economic policies for right prediction of change in stock prices and performance of US stock market. As Hoque and Zaidi (2018) also concluded that EPU impact on sectoral returns should be considered as a part of systematic risk. Industrial level analysis of US equity market returns concludes that EPU contribute positively towards long run volatility of industrial and material industries however negatively towards consumer staples, health care, information technology and materials (also see Yu et al., 2018). These results suggest that US sectoral returns are sensitive to the economic policy uncertainty however the direction of this sensitivity varies across sectors. Such effects of EPU on sectoral equity returns lead towards market volatility due to which policy makers sometime have make policy adjustments. However, this can further increase uncertainty and volatility in the equity 
market (Antonakakis et al., 2013; Li et al., 2016). Results of this study also support Antonakakis et al. (2017), Phan et al., (2018), Yu et al. (2018) and Yu et al. (2018) observation on US stock market; EPU possessing predictive information on sectoral stock returns, however, these predictions are strong in estimating long-run returns volatility with magnitude of EPU varying across industries. Our findings are also consistent with results of Baker et al. (2016) on stock level data for 12 different countries. As government policy maker usually do not agree on frequent changes in economic policies and delay in their consensus contributes to economic uncertainty ( $\mathrm{Li}$ et al., 2016), such uncertainties increase equity risk premium and therefore increase stock prices. Which can result in ups and down of stock markets especially in the periods of turmoil. These results are also useful for funds manager and individual trader for portfolio construction and risk diversification. Knowledge on the nature and direction of relationship between sectoral returns and EPU both in short and long run can help the investor to choose the sector which is either less effected or can help in mitigation of risk associated with policy uncertainties. Investigation of non-linear relationship between economic policy uncertainty and US sector based returns has implications for investors as well as policy makers. The sensitivity of sectoral returns to EPU with their varying responses help in identifying sectors, more volatile for investment purposes under economic turbulent periods. Similarly, less explanation of sectoral returns attributable to EPU highlight sectors with more diversification benefits during periods of economic downturns. Therefore, our work present implications for investors with risk averse behavior, not interested for investments during stable economic regimes. Furthermore, the results on short- and long-run relationship between US sectoral returns and EPU have implications for short-term and long term investments, respectively given the non-linear relationship. Policy makers also use insights from the nonlinear relationship between EPU and sectoral returns as effect of economic policy uncertainty is not solely on sector based returns but on other channels as well through which the changes are transmitted to equity returns. 


\section{References}

Aastveit, K., Natvik, G.J.J. and Sola, S., 2013. Economic uncertainty and the effectiveness of monetary policy.

Adjei, F.A. and Adjei, M., 2017. Economic policy uncertainty, market returns and expected return predictability. Journal of Financial Economic Policy, 9(3), pp.242-259.

Ali, A.M., 2001. Political instability, policy uncertainty, and economic growth: An empirical investigation. Atlantic Economic Journal, 29(1), pp.87-106.

Aloui, C., Nguyen, D.K. and Njeh, H., 2012. Assessing the impacts of oil price fluctuations on stock returns in emerging markets. Economic Modelling, 29(6), pp.2686-2695.

Antonakakis, N., Babalos, V. and Kyei, C., 2016. Predictability of sustainable investments and the role of uncertainty: evidence from a non-parametric causality-in-quantiles test. Applied Economics, 48(48), pp.4655-4665.

Antonakakis, N., Balcilar, M., Gupta, R. and Kyei, C., 2017. Components of economic policy uncertainty and predictability of US stock returns and volatility: evidence from a nonparametric causality-in-quantile approach. Frontiers in Finance and Economics, 14(2), pp.20-49.

Antonakakis, N., Chatziantoniou, I. and Filis, G., 2013. Dynamic co-movements of stock market returns, implied volatility and policy uncertainty. Economics Letters, 120(1), pp.87-92.

Arbatli, E.C., Davis, S.J., Ito, A., Miake, N. and Saito, I., 2017. Policy uncertainty in japan (No. w23411). National Bureau of Economic Research.

Arouri, M. and Roubaud, D., 2016. On the determinants of stock market dynamics in emerging countries: the role of economic policy uncertainty in China and India. Economics Bulletin, 36(2), pp.760-770.

Arouri, M., Rault, C. and Teulon, F., 2014. Economic policy uncertainty, oil price shocks and GCC stock markets. Economics Bulletin, 34(3), pp.1822-1834.

Bachmann, R., Elstner, S. and Sims, E.R., 2013. Uncertainty and economic activity: Evidence from business survey data. American Economic Journal: Macroeconomics, 5(2), pp.21749. 
Badshah, I., Demirer, R. and Suleman, T., 2018. The effect of economic policy uncertainty on stock-commodity correlations and its implications on optimal hedging. Available at SSRN 3240962.

Baker, S.R., Bloom, N. and Davis, S.J., 2016. Measuring economic policy uncertainty. The Quarterly Journal of Economics, 131(4), pp.1593-1636.

Balcilar, M., Gupta, R. and Pierdzioch, C., 2016. Does uncertainty move the gold price? New evidence from a nonparametric causality-in-quantiles test. Resources Policy, 49, pp.7480.

Balcilar, M., Gupta, R., Kim, W.J. and Kyei, C., 2015. The role of domestic and global economic policy uncertainties in predicting stock returns and their volatility for Hong Kong, Malaysia and South Korea: Evidence from a nonparametric causality-in-quantiles approach. Department of Economics, University of Pretoria, Working Paper No, 201586.

Banerjee, A., Dolado, J. and Mestre, R., 1998. Error-correction mechanism tests for cointegration in a single-equation framework. Journal of time series analysis, 19(3), pp.267-283.

Baum, C.F., Caglayan, M. and Talavera, O., 2009. On the sensitivity of firms' investment to cash flow and uncertainty. Oxford Economic Papers, 62(2), pp.286-306.

Beckmann, J. and Czudaj, R., 2017. Exchange rate expectations and economic policy uncertainty. European Journal of Political Economy, 47, pp.148-162.

Bekiros, S., Gupta, R. and Kyei, C., 2016. On economic uncertainty, stock market predictability and nonlinear spillover effects. The North American journal of economics and finance, 36, pp.184-191.

Bernanke, B.S., 1983. Irreversibility, uncertainty, and cyclical investment. The Quarterly Journal of Economics, 98(1), pp.85-106.

Bhagat, S., Ghosh, P. and Rangan, S.P., 2013. Economic policy uncertainty and economic growth in India.

Bloom, N. and Van Reenen, J., 2007. Measuring and explaining management practices across firms and countries. The Quarterly Journal of Economics, 122(4), pp.1351-1408.

Bloom, N., 2009. The impact of uncertainty shocks. econometrica, 77(3), pp.623-685.

Boutchkova, M., Doshi, H., Durnev, A. and Molchanov, A., 2011. Precarious politics and return volatility. The Review of Financial Studies, 25(4), pp.1111-1154. 
Brogaard, J. and Detzel, A., 2015. The asset-pricing implications of government economic policy uncertainty. Management Science, 61(1), pp.3-18.

Broock, W.A., Scheinkman, J.A., Dechert, W.D. and LeBaron, B., 1996. A test for independence based on the correlation dimension. Econometric reviews, 15(3), pp.197235.

Chang, T., Chen, W.Y., Gupta, R. and Nguyen, D.K., 2015. Are stock prices related to the political uncertainty index in OECD countries? Evidence from the bootstrap panel causality test. Economic Systems, 39(2), pp.288-300.

Chen, J., Jiang, F. and Tong, G., 2017. Economic policy uncertainty in China and stock market expected returns. Accounting \& Finance, 57(5), pp.1265-1286.

Chen, Q., Filardo, A., He, D. and Zhu, F., 2016. Financial crisis, US unconventional monetary policy and international spillovers. Journal of International Money and Finance, 67, pp.62-81.

Christou, C., Cunado, J., Gupta, R. and Hassapis, C., 2017. Economic policy uncertainty and stock market returns in PacificRim countries: Evidence based on a Bayesian panel VAR model. Journal of Multinational Financial Management, 40, pp.92-102.

Dakhlaoui, I. and Aloui, C., 2016. The interactive relationship between the US economic policy uncertainty and BRIC stock markets. International Economics, 146, pp.141-157.

Diks, C., \& Panchenko, V. (2006). A new statistic and practical guidelines for nonparametric Granger causality testing. Journal of Economic Dynamics and Control, 30(9-10), pp. 1647-1669.

Donadelli, M. and Persha, L., 2014. Understanding emerging market equity risk premia: Industries, governance and macroeconomic policy uncertainty. Research in International Business and Finance, 30, pp.284-309.

Engle, R.F. and Granger, C.W., 1987. Co-integration and error correction: representation, estimation, and testing. Econometrica: journal of the Econometric Society, pp.251-276.

Fang, L., Yu, H. and Li, L., 2017. The effect of economic policy uncertainty on the long-term correlation between US stock and bond markets. Economic Modelling, 66, pp.139-145.

Fernández-Villaverde, J., Guerrón-Quintana, P., Kuester, K. and Rubio-Ramírez, J., 2015. Fiscal volatility shocks and economic activity. American Economic Review, 105(11), pp.3352-84. 
Gao, R. and Zhang, B., 2016. How does economic policy uncertainty drive gold-stock correlations? Evidence from the UK. Applied Economics, 48(33), pp.3081-3087.

Giavazzi, F. and McMahon, M., 2012. Policy uncertainty and household savings. Review of Economics and Statistics, 94(2), pp.517-531.

Gulen, H. and Ion, M., 2015. Policy uncertainty and corporate investment. The Review of Financial Studies, 29(3), pp.523-564.

Handley, K. and Limao, N., 2015. Trade and investment under policy uncertainty: theory and firm evidence. American Economic Journal: Economic Policy, 7(4), pp.189-222.

Hassett, K.A. and Metcalf, G.E., 1999. Investment with uncertain tax policy: Does random tax policy discourage investment. The Economic Journal, 109(457), pp.372-393.

Higgs, R., 1997. Regime uncertainty: why the Great Depression lasted so long and why prosperity resumed after the war. The Independent Review, 1(4), pp.561-590.

Hoque, M.E. and Zaidi, M.A.S., 2018. The impacts of global economic policy uncertainty on stock market returns in regime switching environment: Evidence from sectoral perspectives. International Journal of Finance \& Economics.

Jones, C.M. and Kaul, G., 1996. Oil and the stock markets. The Journal of Finance, 51(2), pp.463-491.

Jones, P.M. and Olson, E., 2013. The time-varying correlation between uncertainty, output, and inflation: Evidence from a DCC-GARCH model. Economics Letters, 118(1), pp.3337.

Kang, W. and Ratti, R.A., 2013. Oil shocks, policy uncertainty and stock market return. Journal of International Financial Markets, Institutions and Money, 26, pp.305318.

Kang, W., de Gracia, F.P. and Ratti, R.A., 2017. Oil price shocks, policy uncertainty, and stock returns of oil and gas corporations. Journal of International Money and Finance, 70, pp.344-359.

Kang, W., Lee, K. and Ratti, R.A., 2014. Economic policy uncertainty and firm-level investment. Journal of Macroeconomics, 39, pp.42-53.

Kurov, A. and Stan, R., 2018. Monetary policy uncertainty and the market reaction to macroeconomic news. Journal of Banking \& Finance, 86, pp.127-142. 
Lean, H.H. and Nguyen, D.K., 2014. Policy uncertainty and performance characteristics of sustainable investments across regions around the global financial crisis. Applied Financial Economics, 24(21), pp.1367-1373.

Leduc, S. and Liu, Z., 2016. Uncertainty shocks are aggregate demand shocks. Journal of Monetary Economics, 82, pp.20-35.

Li, X.L., Balcilar, M., Gupta, R. and Chang, T., 2016. The causal relationship between economic policy uncertainty and stock returns in China and India: evidence from a bootstrap rolling window approach. Emerging Markets Finance and Trade, 52(3), pp.674-689.

Marcus, A.A., 1981. Policy uncertainty and technological innovation. Academy of Management Review, 6(3), pp.443-448.

Mensi, W., Hammoudeh, S., Reboredo, J.C. and Nguyen, D.K., 2014. Do global factors impact BRICS stock markets? A quantile regression approach. Emerging Markets Review, 19, pp.1-17.

Momin, E. and Masih, M., 2015. Do US policy uncertainty, leveraging costs and global risk aversion impact emerging market equities? An application of bounds testing approach to the BRICS.

Nagar, V., Schoenfeld, J. and Wellman, L., 2018. Economic Policy Uncertainty, Information Asymmetry, and Firm Disclosure.

Nusair, S. A. (2016). The effects of oil price shocks on the economies of the Gulf Cooperation Council countries: Nonlinear analysis. Energy Policy, 91, 256-267.

Ozoguz, A., 2008. Good times or bad times? Investors' uncertainty and stock returns. The Review of financial studies, 22(11), pp.4377-4422.

Pastor, L. and Veronesi, P., 2012. Uncertainty about government policy and stock prices. The Journal of Finance, 67(4), pp.1219-1264.

Pástor, L. and Veronesi, P., 2013. Political uncertainty and risk premia. Journal of Financial Economics, 110(3), pp.520-545.

Pesaran, M. H., Shin, Y., \& Smith, R. J. (2001). Bounds testing approaches to the analysis of level relationships. Journal of applied econometrics, 16(3), 289-326.

Pesaran, M.H. and Shin, Y., 1998. An autoregressive distributed-lag modelling approach to cointegration analysis. Econometric Society Monographs, 31, pp.371-413. 
Phan, D.H.B., Sharma, S.S. and Tran, V.T., 2018. Can economic policy uncertainty predict stock returns? Global evidence. Journal of International Financial Markets, Institutions and Money, 55, pp.134-150.

Rapach, D. and Zhou, G., 2013. Forecasting stock returns. In Handbook of economic forecasting (Vol. 2, pp. 328-383). Elsevier.

Rehman, M.U., 2018. Do oil shocks predict economic policy uncertainty? Physica A: Statistical Mechanics and its Applications, 498, pp.123-136.

Rehman, M.U., Shahzad, S.J.H., Uddin, G.S. and Hedström, A., 2018. Precious metal returns and oil shocks: A time varying connectedness approach. Resources Policy, 58, pp.77-89.

Rodrik, D., 1991. Policy uncertainty and private investment in developing countries. Journal of Development Economics, 36(2), pp.229-242.

Romilly, P., Song, H., \& Liu, X. (2001). Car ownership and use in Britain: a comparison of the empirical results of alternative cointegration estimation methods and forecasts. Applied economics, 33(14), 1803-1818.

Scotti, C., 2016. Surprise and uncertainty indexes: Real-time aggregation of real-activity macro-surprises. Journal of Monetary Economics, 82, pp.1-19.

Shahzad, S. J. H., Nor, S. M., Ferrer, R. and Hammoudeh, S., 2017. Asymmetric determinants of CDS spreads: U.S. industry-level evidence through the NARDL approach. Economic Modelling, 60, pp. 211-230

Shahzad, S.J.H., Rehman, M.U. and Jammazi, R., 2018. Spillovers from oil to precious metals: Quantile approaches. Resources Policy.

Shin, Y., Yu, B. and Greenwood-Nimmo, M., 2014. Modelling asymmetric cointegration and dynamic multipliers in a nonlinear ARDL framework. In Festschrift in Honor of Peter Schmidt (pp. 281-314). Springer, New York, NY.

Shin, Y., Yu, B., \& Greenwood-Nimmo, M. (2014). Modelling asymmetric cointegration and dynamic multipliers in a nonlinear ARDL framework. In Festschrift in honor of Peter Schmidt (pp. 281-314). Springer, New York, NY.

Sum, V., 2013. The ASEAN stock market performance and economic policy uncertainty in the United States. Economic Papers: A journal of applied economics and policy, 32(4), pp.512-521. 
Tsai, I.C., 2017. The source of global stock market risk: A viewpoint of economic policy uncertainty. Economic Modelling, 60, pp.122-131.

Uddin, G.S., Rahman, M.L., Shahzad, S.J.H. and Rehman, M.U., 2018. Supply and demand driven oil price changes and their non-linear impact on precious metal returns: A Markov regime switching approach. Energy Economics, 73, pp.108-121.

Wu, T.P., Liu, S.B. and Hsueh, S.J., 2016. The causal relationship between economic policy uncertainty and stock market: a panel data analysis. International Economic Journal, 30(1), pp.109-122.

Yu, H., Fang, L. and Sun, B., 2018. The role of global economic policy uncertainty in longrun volatilities and correlations of US industry-level stock returns and crude oil. PloS one, 13(2), p.e 0192305.

Yu, H., Fang, L., Du, D. and Yan, P., 2017. How EPU drives long-term industry beta. Finance Research Letters, 22, pp.249-258.

Yu, H., Fang, L., Zhang, S. and Du, D., 2018. The role of the political cycle in the relationship between economic policy uncertainty and the long-run volatility of industry-level stock returns in the United States. Applied Economics, 50(26), pp.2932-2937. 
Table 1: Market capitalization of sampled sectors ${ }^{3}$

\begin{tabular}{lcclcc}
\hline Name & Stock Count & Market Cap & Name & Stock Count & Market Cap \\
\hline INFOTECH & 710 & $\$ 9.187$ & UTILITIES & 132 & $\$ 1.402$ \\
FINANCIALS & 1176 & $\$ 8.412$ & INDUSTRIALS & 210 & $\$ 0.909$ \\
HEALTH CARE & 761 & $\$ 4.405$ & AUTOMOBILES & 147 & $\$ 0.840$ \\
CONSUMER & 276 & $\$ 2.069$ & TELECOM & 16 & $\$ 0.266$ \\
DISCRETIONARY & & $\$ 1.405$ & UNCLASSIFIED & 31 & $\$ 0.011$ \\
MATERIALS & 187 & & & & \\
\hline
\end{tabular}

Table 2: Descriptive Statistics

\begin{tabular}{|c|c|c|c|c|c|c|c|c|c|c|}
\hline & $\begin{array}{l}\text { HEALTH } \\
\text { CARE }\end{array}$ & $\begin{array}{c}\text { CONSUMER } \\
\text { DISCRETION } \\
\text { ARY } \\
\end{array}$ & FINANCIALS & INDUSTRIALS & TELECOM & MATERIALS & INFOTECH & UTILITIES & $\begin{array}{c}\text { AUTO } \\
\text { MOBILES }\end{array}$ & EPU \\
\hline Mean & 0.0019 & 0.0017 & 0.0014 & 0.0014 & 0.0004 & 0.0009 & 0.0018 & 0.0007 & 0.0000 & 4.5807 \\
\hline Median & 0.0028 & 0.0033 & 0.0027 & 0.0029 & 0.0017 & 0.0027 & 0.0033 & 0.0026 & 0.0013 & 4.5400 \\
\hline Max & 0.1132 & 0.1148 & 0.1486 & 0.0886 & 0.1051 & 0.0900 & 0.1142 & 0.0946 & 0.2863 & 5.6086 \\
\hline Min & -0.1254 & -0.1682 & -0.2497 & -0.1473 & -0.1828 & -0.1572 & -0.1492 & -0.1481 & -0.3497 & 3.8981 \\
\hline Std. Dev. & 0.0194 & 0.0233 & 0.0345 & 0.0229 & 0.0238 & 0.0260 & 0.0303 & 0.0201 & 0.0418 & 0.2774 \\
\hline Skew. & -0.5924 & -0.7071 & -0.9742 & -0.8271 & -0.6500 & -0.5782 & -0.4763 & -0.9935 & -0.4310 & 0.5524 \\
\hline Kurt. & 7.3196 & 8.1607 & 11.2318 & 7.9990 & 8.6137 & 6.4270 & 5.1609 & 8.9587 & 13.6587 & 3.3814 \\
\hline JB Stat & $915.4^{*}$ & $1306.3^{*}$ & $3264.9 *$ & $1265.0^{*}$ & 1514.9* & $596.8^{*}$ & $254.5^{*}$ & $1800.1^{*}$ & $5217.2^{*}$ & $62.3^{*}$ \\
\hline Corr. & 0.0113 & -0.0306 & -0.0289 & -0.0385 & -0.0355 & -0.0546 & -0.0463 & -0.0441 & -0.0551 & 1 \\
\hline GLS & $-6.25^{*}$ & $-5.66^{*}$ & $-76.99 *$ & $-75.67^{*}$ & $-76.25^{*}$ & $-10.22^{*}$ & $-4.08^{*}$ & $-7.69 *$ & $-5.66^{*}$ & -6.3200 \\
\hline KPSS & 0.3500 & 0.1200 & 0.4100 & 0.1300 & 0.1800 & 0.0300 & 0.2000 & 0.0600 & 0.0900 & 0.6530 \\
\hline$Q(20)$ & $61.05^{*}$ & $46.19 *$ & $110.49 *$ & $58.44^{*}$ & $49.88^{*}$ & $43.84^{*}$ & $40.27^{*}$ & $46.66^{*}$ & $47.72^{*}$ & $8768.5^{*}$ \\
\hline Q2(20) & 20.4500 & 13.6600 & $34.61 *$ & 21.0600 & 15.1700 & 24.5000 & 24.1700 & $36.11^{*}$ & 16.2600 & $3992.8^{*}$ \\
\hline $\operatorname{ARCH}(20)$ & 1.0200 & 0.6900 & $1.69 *$ & 1.0900 & 0.8100 & 1.2400 & 1.3000 & $1.86^{*}$ & 0.9200 & 121.49* \\
\hline
\end{tabular}

Table 3: BDS Test Statistics

\begin{tabular}{lccccc}
\hline Commodity Futures & $\mathrm{m}$ & \multicolumn{5}{l}{} \\
\hline \multicolumn{1}{l}{ Panel 1 with EPU: } & 2 & 3 & 4 & 5 & 6 \\
Health care & $0.1772^{*}$ & $0.2948^{*}$ & $0.3704^{*}$ & $0.4171^{*}$ & $0.4438^{*}$ \\
Consumer & $0.1781^{*}$ & $0.2961^{*}$ & $0.3718^{*}$ & $0.4186^{*}$ & $0.4455^{*}$ \\
Discretionary & $0.0302^{*}$ & $0.0545^{*}$ & $0.0777^{*}$ & $0.0892^{*}$ & $0.0927^{*}$ \\
Financials & $0.0280^{*}$ & $0.0546^{*}$ & $0.0720^{*}$ & $0.0834^{*}$ & $0.0886^{*}$ \\
Industrials & $0.0199^{*}$ & $0.0412^{*}$ & $0.0583^{*}$ & $0.0675^{*}$ & $0.074^{*}$ \\
Telecom & $0.0140^{*}$ & $0.0319^{*}$ & $0.0444^{*}$ & $0.0528^{*}$ & $0.0546^{*}$ \\
Materials & $0.0196^{*}$ & $0.0377^{*}$ & $0.0491^{*}$ & $0.0563^{*}$ & $0.0587^{*}$ \\
Info Tech & $0.1759^{*}$ & $0.2931^{*}$ & $0.3683^{*}$ & $0.4146^{*}$ & $0.4411^{*}$ \\
Utilities & $0.1772^{*}$ & $0.2948^{*}$ & $0.3704^{*}$ & $0.4171^{*}$ & $0.4438^{*}$ \\
\hline Automobiles &
\end{tabular}

Notes: $\mathrm{m}$ denotes the parameter $\mathrm{m}$ in the embedding dimension and $\varepsilon$ is the epsilon values. $P$ values are reported in parenthesis.

\footnotetext{
${ }^{3}$ Unit of market capitalization for all the sectors is in trillions of Unites States dollars.
} 
Table 4: Non-Linear Granger Causality

\begin{tabular}{lccc}
\hline US Sectoral & \multicolumn{3}{c}{$\mathrm{H}_{0}$ : EPU does not Granger cause US sectoral returns } \\
\cline { 2 - 4 } Returns & $\begin{array}{c}\text { Embedding } \\
\text { dimension } \\
\boldsymbol{m = 1}\end{array}$ & $\begin{array}{c}\text { Embedding } \\
\text { dimension } \\
\boldsymbol{m = 2}\end{array}$ & $\begin{array}{c}\text { Embedding } \\
\text { dimension } \\
\boldsymbol{m}=\mathbf{3}\end{array}$ \\
\hline Health care & 0.267 & -0.056 & 0.953 \\
Consumer & 0.222 & -0.053 & 0.444 \\
Discretionary & 2.075 & 1.662 & 1.171 \\
Financials & 1.384 & 0.446 & -0.152 \\
Industrials & 0.811 & 0.592 & -0.397 \\
Telecom & 0.792 & 0.498 & -0.582 \\
Materials & 0.937 & 0.119 & -0.460 \\
Info Tech & -0.154 & -0.547 & 0.103 \\
Utilities & 2.049 & 1.728 & 1.043 \\
Automobiles & & & \\
\hline
\end{tabular}

Table 5: Co-integration Critical Values

\begin{tabular}{|c|c|c|c|c|}
\hline \multirow[b]{2}{*}{ Statistics } & \multicolumn{2}{|c|}{$\mathrm{k}=1(95 \%)$} & \multicolumn{2}{|c|}{$\mathrm{k}=2(95 \%)$} \\
\hline & $\mathbf{I}(\overline{\mathbf{0})}$ & $\mathbf{I}(\mathbf{1})$ & $\overline{\mathbf{I}(\mathbf{0})}$ & $\mathbf{I}(\mathbf{1})$ \\
\hline$t_{B D M}$ & -2.86 & -3.22 & -2.86 & -3.53 \\
\hline \multirow[t]{2}{*}{$F_{P S S}$} & $\begin{array}{c}4.94 \\
\mathbf{k}=\end{array}$ & 5.73 & $\begin{array}{c}3.79 \\
\mathbf{k}=\end{array}$ & 4.85 \\
\hline & $\mathbf{I}(\overline{\mathbf{0})}$ & I(1) & $\mathbf{I}(\mathbf{0})$ & $\mathbf{I}(\mathbf{1})$ \\
\hline$t_{B D M}$ & -2.57 & -2.91 & -2.57 & -3.21 \\
\hline$F_{P S S}$ & 4.04 & 4.78 & 3.17 & 4.14 \\
\hline
\end{tabular}

Table 6: Estimation Results-NARDL-Automobiles

\begin{tabular}{|c|c|c|c|c|c|c|c|}
\hline \multicolumn{2}{|c|}{ Symmetric ARDL } & \multicolumn{2}{|c|}{$\frac{\text { NARDL with SR \& LR }}{\text { asymmetry }}$} & \multicolumn{2}{|c|}{ NARDL with LR asymmetry } & \multicolumn{2}{|c|}{ NARDL with SR asymmetry } \\
\hline Variable & Coefficients & Variable & Coefficients & Variable & Coefficients & Variable & Coefficients \\
\hline Intercept & $0.0297(0.0639)$ & Intercept & $0.2862 *(0.0854)$ & Intercept & $0.2671 *(0.0856)$ & Intercept & $0.0512(0.0609)$ \\
\hline $\mathrm{RET}_{\mathrm{t}-1}$ & $-0.0059(0.0058)$ & $\mathrm{RET}_{\mathrm{t}-1}$ & $-0.0617 *(0.0188)$ & $\mathrm{RET}_{\mathrm{t}-1}$ & $-0.0581 *(0.0186)$ & $\mathrm{RET}_{\mathrm{t}-1}$ & $-0.0066(0.0058)$ \\
\hline$E P U_{t-1}$ & $0.0007(0.0098)$ & $\mathrm{EPU}^{+} \mathrm{t}-1$ & $0.0016(0.0093)$ & $\mathrm{EPU}^{+} \mathrm{t}-1$ & $0.0037(0.0097)$ & $E P U_{t-1}$ & $-0.0027(0.0093)$ \\
\hline$\Delta \mathrm{RET}_{\mathrm{t}-1}$ & $0.1742 *(0.0621)$ & $\mathrm{EPU}_{\mathrm{t}-1}^{-}$ & $-0.0097(0.0094)$ & $E P U^{-}-1$ & $-0.0070(0.0010)$ & $\Delta \mathrm{RET}_{\mathrm{t}-1}$ & $0.1748 *(0.0622)$ \\
\hline$\Delta \mathrm{EPU}_{\mathrm{t}-6}$ & $-0.0748 * *(0.0371)$ & $\Delta \mathrm{RET}_{\mathrm{t}-1}$ & $0.2002 *(0.0617)$ & $\Delta \mathrm{RET}_{\mathrm{t}-1}$ & $0.01991 *(0.0618)$ & $\Delta \mathrm{EPU}^{+}{ }_{\mathrm{t}-7}$ & $-0.1667 *(0.0690)$ \\
\hline$\triangle \mathrm{EPU}_{\mathrm{t}-9}$ & $-0.1113 *(0.0443)$ & $\Delta \mathrm{EPU}^{+}{ }_{\mathrm{t}-8}$ & $0.2195 *(0.0847)$ & $\Delta \mathrm{EPU}^{+}{ }_{\mathrm{t}-9}$ & $-0.1167 *(0.0437)$ & $\Delta \mathrm{EPU}^{+}{ }_{\mathrm{t}-9}$ & $-0.1576 *(0.0685)$ \\
\hline \multirow[t]{2}{*}{$\triangle \mathrm{EPU}_{\mathrm{t}-8}$} & $0.0899 * *(0.0480)$ & $\Delta \mathrm{EPU}_{\mathrm{t}-7}^{+}$ & $-0.1676 *(0.0678)$ & $\Delta \mathrm{EPU}^{+}{ }_{\mathrm{t}-8}$ & $0.0886 * *(0.0472)$ & $\Delta \mathrm{EPU}^{+}{ }_{\mathrm{t}-8}$ & $0.2244 *(0.0862)$ \\
\hline & & $\Delta \mathrm{EPU}^{+}{ }_{\mathrm{t}-8}$ & $-0.1767 *(0.0677)$ & $\Delta \mathrm{EPU}^{+}{ }_{\mathrm{t}-6}$ & $-0.0729 *(0.0366)$ & & \\
\hline \multirow[t]{2}{*}{$\mathrm{L}_{\text {EPU }}$} & $0.1186^{*}$ & $\mathrm{LEPU}^{+}$ & $0.0259 *$ & $\mathrm{LEPU}^{+}$ & $0.0637^{*}$ & $\mathrm{~L}_{\text {EPU }}$ & $-0.4091 *$ \\
\hline & & $\mathrm{LEPU}^{-}$ & $-0.1572 *$ & LePU $^{-}$ & $-0.1205^{*}$ & & \\
\hline$R^{2}$ & 0.0706 & $\mathrm{R}^{2}$ & 0.1112 & $\mathrm{R}^{2}$ & 0.1016 & $\mathrm{R}^{2}$ & 0.0768 \\
\hline Adj. $R^{2}$ & 0.0478 & Adj. $R^{2}$ & 0.0857 & Adj. $R^{2}$ & 0.0759 & Adj. $R^{2}$ & 0.0542 \\
\hline $\mathrm{X}^{2}{ }_{\mathrm{BG}}$ & $0.7666[0.4657]$ & $X^{2}{ }_{B G}$ & $0.4619[0.6306]$ & $X^{2}{ }_{B G}$ & $0.6500[0.5230]$ & $X^{2} B G$ & $1.0763[0.3425]$ \\
\hline $\mathrm{X}^{2}{ }_{\mathrm{RR}}$ & $0.0170[0.8965]$ & $X^{2}{ }_{R R}$ & $0.8045[0.3706]$ & $X^{2}{ }_{R R}$ & 0.5974 [0.4403] & $X^{2}{ }_{R R}$ & $0.0702[0.7913]$ \\
\hline$X^{2}{ }_{J B}$ & $40.9819[0.0000]$ & $\mathrm{X}^{2}{ }_{\mathrm{JB}}$ & $38.2547[0.0000]$ & $X^{2}{ }_{J B}$ & $37.9610[0.0000]$ & $\mathrm{X}^{2} \mathrm{JB}$ & $41.4647[0.0000]$ \\
\hline$t_{\mathrm{BDM}}$ & $-3.2818[0.0003]$ & $t_{\mathrm{BDM}}$ & $-3.2818[0.0124]$ & $t_{\mathrm{BDM}}$ & -3.2818 & $t_{\mathrm{BDM}}$ & -3.2818 \\
\hline \multirow[t]{3}{*}{$F_{\mathrm{PSS}}$} & $0.6892[0.5030]$ & $F_{\mathrm{PSS}}$ & $3.6205[0.0138]$ & $F_{\mathrm{PSS}}$ & 3.2855 [0.0215] & $F_{\mathrm{PSS}}$ & $0.6832[0.5060]$ \\
\hline & & $W_{L R}$ & $103.5364[0.0000]$ & $W_{L R}$ & $90.9584[0.0000]$ & & \\
\hline & & $W_{S R}$ & $4.5937[0.0331]$ & & & $W_{S R}$ & $2.8968[0.0900]$ \\
\hline
\end{tabular}

Notes: In the above table, we use general to specific approach to select the best ARDL specification. To do this, we use maximum value of $\mathrm{p}=12$; $\mathrm{q}=12$ and by dropping insignificant values following the stepwise regression. The long run coefficients are represented by $\mathrm{L}_{\mathrm{EPU}}, \mathrm{L}_{\mathrm{EPU}}{ }^{+}$and $\mathrm{L}_{\mathrm{EPU}} \mathrm{X}^{-}$for unitary, positive and negative economic policy uncertainty shocks, respectively. $\mathrm{X}_{\mathrm{BG}}^{2}, \mathrm{X}_{\mathrm{RR}}{ }_{\mathrm{R}}$ and $\mathrm{X}_{\mathrm{JB}}^{2}$ denotes statistics for serial correlation, functional forms and normality tests. Expression of Wald test are presented by $\mathrm{W}_{\mathrm{LR}}$ and $\mathrm{W}_{\mathrm{SR}}$ for long- and short-run asymmetry. Standard errors are presented in parenthesis 
whereas associated p-values are contained in brackets. Finally, ${ }^{* * *},{ }^{*}$ and ${ }^{* * *}$ denotes significance at 1,5 and 10 percent levels, respectively.

Table 7: Estimation Results-NARDL-Consumer Discretionary

\begin{tabular}{|c|c|c|c|c|c|c|c|}
\hline \multicolumn{2}{|c|}{ Symmetric ARDL } & \multicolumn{2}{|c|}{$\frac{\text { NARDL with SR \& LR }}{\text { asymmetry }}$} & \multicolumn{2}{|c|}{ NARDL with LR asymmetry } & \multicolumn{2}{|c|}{ NARDL with SR asymmetry } \\
\hline Variable & Coefficients & Variable & Coefficients & Variable & Coefficients & Variable & Coefficients \\
\hline $\mathrm{C}$ & $0.0185(0.0422)$ & $\mathrm{C}$ & $0.3764 *(0.0971)$ & $\mathrm{C}$ & $0.3645 *(0.0982)$ & $\mathrm{C}$ & $-0.0001(0.0450)$ \\
\hline $\mathrm{RET}_{\mathrm{t}-1}$ & $-0.0016(0.0043)$ & $\mathrm{RET}_{\mathrm{t}-1}$ & $-0.0814 *(0.0211)$ & $\operatorname{RET}_{\mathrm{t}-1}$ & $-0.0789 *(0.0214)$ & $\mathrm{RET}_{\mathrm{t}-1}$ & $-0.0005(0.0043)$ \\
\hline$E P U_{t-1}$ & $-0.0005(0.0061)$ & $\mathrm{EPU}^{+}{ }_{\mathrm{t}-1}$ & $0.0039(0.0065)$ & $\mathrm{EPU}^{+}{ }_{\mathrm{t}-1}$ & $0.0061(0.0068)$ & $\mathrm{EPU}_{\mathrm{t}-1}$ & $0.0017(0.0067)$ \\
\hline$\Delta \mathrm{RET}_{\mathrm{t}-1}$ & $0.1470 *(0.0632)$ & $E P U^{-}-1$ & $\begin{array}{l}-0.0114 \\
(0.0070)\end{array}$ & $E P U^{-} t-1$ & $\begin{array}{l}-0.0088 \\
(0.0075)\end{array}$ & $\Delta \mathrm{RET}_{\mathrm{t}-1}$ & $0.1611 *(0.0628)$ \\
\hline$\Delta \mathrm{RET}_{\mathrm{t}-12}$ & $-0.1299 *(0.0639)$ & $\Delta \mathrm{RET}_{\mathrm{t}-1}$ & $0.1995 *(0.0618)$ & $\Delta \mathrm{RET}_{\mathrm{t}-1}$ & $0.1881 *(0.0622)$ & $\Delta \mathrm{EPU}^{+}{ }_{\mathrm{t}-9}$ & $-0.1269 *(0.0487)$ \\
\hline \multirow[t]{4}{*}{$\Delta \mathrm{RET}_{\mathrm{t}-4}$} & $0.1245^{*}(0.0635)$ & $\Delta \mathrm{RET}_{\mathrm{t}-4}$ & $0.1555^{*}(0.0613)$ & $\Delta \mathrm{RET}_{\mathrm{t}-4}$ & $0.1533 *(0.0621)$ & $\Delta \mathrm{RET}_{\mathrm{t}-4}$ & $0.1208 * *(0.0624)$ \\
\hline & & $\Delta \mathrm{EPU}^{+} \mathrm{t}-9$ & $-0.1292 *(0.0473)$ & $\triangle \mathrm{EPU}_{\mathrm{t}-8}$ & $0.0730 *(0.0331)$ & $\Delta \mathrm{EPU}^{-} \mathrm{t}-6$ & $-0.0937 *(0.0434)$ \\
\hline & & $\Delta \mathrm{EPU}^{+}{ }_{\mathrm{t}-7}$ & $-0.1069 *(0.0472)$ & $\triangle \mathrm{EPU}_{\mathrm{t}-9}$ & $-0.0602 *(0.0308)$ & $\Delta E P U^{-}{ }_{t-8}$ & $0.1503 *(0.0492)$ \\
\hline & & $\Delta \mathrm{EPU}^{+}{ }_{\mathrm{t}-8}$ & $0.2023 *(0.0590)$ & $\Delta \mathrm{EPU}_{\mathrm{t}-6}$ & $-0.0518^{*}(0.0256)$ & & \\
\hline \multirow[t]{2}{*}{ LEPU } & $-0.3125^{*}$ & $\mathrm{LEPU}^{+}$ & $0.0479 *$ & $\mathrm{LEPU}^{+}$ & $0.0773^{*}$ & $\mathrm{~L}_{\text {EPU }}$ & $0.2941^{*}$ \\
\hline & & LEPU $^{-}$ & $-0.1400^{*}$ & LePU $^{-}$ & $-0.1115^{*}$ & & \\
\hline $\mathrm{R}^{2}$ & 0.0506 & $R^{2}$ & 0.1330 & $\mathrm{R}^{2}$ & 0.1119 & $R^{2}$ & 0.0815 \\
\hline Adj. $R^{2}$ & 0.0311 & Adj. $R^{2}$ & 0.1044 & Adj. $R^{2}$ & 0.0827 & Adj. $R^{2}$ & 0.0551 \\
\hline $\mathrm{X}^{2} \mathrm{BG}$ & $0.2891[0.7492]$ & $\mathrm{X}^{2}{ }_{\mathrm{BG}}$ & $0.2212[0.8017]$ & $\mathrm{X}^{2} \mathrm{BG}$ & $0.3213[0.7255]$ & $\mathrm{X}^{2} \mathrm{BG}$ & 0.4819 [0.6182] \\
\hline $\mathrm{X}^{2} \mathrm{RR}$ & $1.1425[0.2862]$ & $\mathrm{X}^{2}{ }_{\mathrm{RR}}$ & $0.9024[0.3431]$ & $X^{2}{ }_{R R}$ & $0.0676[0.7951]$ & $\mathrm{X}^{2}{ }_{\mathrm{RR}}$ & $0.6343[0.4266]$ \\
\hline$X^{2}{ }_{J B}$ & $65.3320[0.0000]$ & $\mathrm{X}^{2} \mathrm{JB}$ & 59.1757 [0.0000] & $\mathrm{X}^{2} \mathrm{JB}$ & $63.1807[0.0000]$ & $\mathrm{X}^{2}{ }_{\mathrm{JB}}$ & $75.5926[0.0000]$ \\
\hline$t_{\mathrm{BDM}}$ & -8.8481 & $t_{\mathrm{BDM}}$ & -3.8481 & $t_{\mathrm{BDM}}$ & -3.8481 & $t_{\mathrm{BDM}}$ & -3.8482 \\
\hline \multirow[t]{3}{*}{$F_{\mathrm{PSS}}$} & $\begin{array}{c}0.0721 \\
{[0.9305]}\end{array}$ & $F_{\mathrm{PSS}}$ & $4.9875[0.0022]$ & $F_{\mathrm{PSS}}$ & $4.7808[0.0030]$ & $F_{\mathrm{PSS}}$ & 0.1635 [0.8493] \\
\hline & & $W_{\mathrm{LR}}$ & $382.5662[0.0000]$ & $W_{\mathrm{LR}}$ & $352.0032[0.0000]$ & & \\
\hline & & $W_{S R}$ & 12.8901 [0.0049] & & & $W_{S R}$ & $3.7771[0.0531]$ \\
\hline
\end{tabular}

Notes: Similar to Table 6

Table 8: Estimation Results-NARDL-Healthcare

\begin{tabular}{|c|c|c|c|c|c|c|c|}
\hline \multicolumn{2}{|c|}{$\underline{\text { Symmetric ARDL }}$} & \multicolumn{2}{|c|}{$\frac{\text { NARDL with SR \& LR }}{\text { asymmetry }}$} & \multicolumn{2}{|c|}{$\underline{\text { NARDL with LR asymmetry }}$} & \multicolumn{2}{|c|}{ NARDL with SR asymmetry } \\
\hline Variable & Coefficients & Variable & Coefficients & Variable & Coefficients & Variable & Coefficients \\
\hline $\mathrm{C}$ & $0.0434(0.0445)$ & $\mathrm{C}$ & $0.0417(0.0854)$ & $\mathrm{C}$ & $0.0028(0.0837)$ & $\mathrm{C}$ & $0.0454(0.0446)$ \\
\hline $\mathrm{RET}_{\mathrm{t}-1}$ & $-0.0015 *(0.0040)$ & RET $_{t-1}$ & $-0.0066(0.0179)$ & $\mathrm{RET}_{\mathrm{t}-1}$ & $0.0019(0.0175)$ & $\mathrm{RET}_{\mathrm{t}-1}$ & $-0.0087 *(0.0040)$ \\
\hline$E P U_{t-1}$ & $0.0081(0.0068)$ & $\mathrm{EPU}^{+}{ }_{\mathrm{t}-1}$ & $0.0012(0.0069)$ & $\mathrm{EPU}^{+}{ }_{\mathrm{t}-1}$ & 0.0009 (0.0069) & $E P U_{t-1}$ & $0.0013(0.0068)$ \\
\hline$\Delta \mathrm{RET}_{\mathrm{t}-12}$ & $-0.1711 *(0.0641)$ & $\mathrm{EPU}_{\mathrm{t}-1}^{-}$ & $0.0017(0.0075)$ & $\mathrm{EPU}^{-} \mathrm{t-1}$ & $0.0032(0.0075)$ & $\Delta \mathrm{RET}_{\mathrm{t}-12}$ & $-0.1737 *(0.0637)$ \\
\hline$\Delta \mathrm{RET}_{\mathrm{t}-3}$ & $-0.1317 *(0.0618)$ & $\Delta \mathrm{RET}_{\mathrm{t}-12}$ & $0.1745^{*}(0.0641)$ & $\Delta \mathrm{RET}_{\mathrm{t}-12}$ & $-0.1747^{*}(0.0645)$ & $\Delta \mathrm{EPU}^{-}$ & $-0.0973 *(0.0457)$ \\
\hline \multirow[t]{3}{*}{$\Delta \mathrm{RET}_{\mathrm{t}-5}$} & $-0.1248 *(0.0633)$ & $\triangle \mathrm{EPU}^{-}$ & $-0.0960 *(0.0470)$ & $\Delta \mathrm{RET}_{\mathrm{t}-3}$ & $-0.1406 *(0.0638)$ & $\Delta \mathrm{RET}_{\mathrm{t}-3}$ & $-0.1301 *(0.0614)$ \\
\hline & & $\Delta \mathrm{RET}_{\mathrm{t}-5}$ & $-0.1296 *(0.0640)$ & $\Delta \mathrm{RET}_{\mathrm{t}-5}$ & $-0.1314 *(0.0644)$ & $\Delta \mathrm{RET}_{\mathrm{t}-5}$ & $-0.1283 *(0.0629)$ \\
\hline & & $\Delta \mathrm{RET}_{\mathrm{t}-3}$ & $-0.1320 *(0.0635)$ & & & & \\
\hline \multirow[t]{2}{*}{ LEPU } & $0.1852^{*}$ & $\mathrm{LEPU}^{+}$ & $0.1818^{*}$ & $\mathrm{LEPU}^{+}$ & $0.4737^{*}$ & $\mathrm{~L}_{\text {EPU }}$ & $0.1494^{*}$ \\
\hline & & $\mathrm{L}_{\mathrm{EPU}}{ }^{-}$ & $0.2576^{*}$ & $\mathrm{~L}_{\mathrm{EPU}}{ }^{-}$ & $0.1684^{*}$ & & \\
\hline$R^{2}$ & 0.0720 & $\mathrm{R}^{2}$ & 0.0890 & $\mathrm{R}^{2}$ & 0.0733 & $\mathrm{R}^{2}$ & 0.0890 \\
\hline Adj. $R^{2}$ & 0.0529 & Adj. $R^{2}$ & 0.0626 & Adj. $R^{2}$ & 0.0503 & Adj. $R^{2}$ & 0.0664 \\
\hline $\mathrm{X}^{2}{ }_{\mathrm{BG}}$ & $1.6810[0.1884]$ & $\mathrm{X}^{2} \mathrm{BG}$ & $1.4334[0.2405]$ & $\mathrm{X}^{2} \mathrm{BG}$ & $1.5284[0.2190]$ & $\mathrm{X}^{2}{ }_{\mathrm{BG}}$ & $1.4262[0.2422]$ \\
\hline$X^{2}{ }_{R R}$ & $0.1356[0.7131]$ & $X^{2}{ }_{R R}$ & $0.1892[0.6640]$ & $X^{2}{ }_{R R}$ & 0.0854 [0.7703] & $X^{2}{ }_{R R}$ & $0.2104[0.6469]$ \\
\hline$X^{2}{ }_{J B}$ & $20.4308[0.0000]$ & $\mathrm{X}^{2} \mathrm{JB}$ & $20.3907[0.0000]$ & $\mathrm{X}^{2} \mathrm{JB}$ & $21.0950[0.0000]$ & $\mathrm{X}^{2} \mathrm{JB}$ & $20.2231[0.0000]$ \\
\hline$t_{\mathrm{BDM}}$ & -0.3698 & $t_{\mathrm{BDM}}$ & -0.3698 & $t_{\mathrm{BDM}}$ & -0.3698 & $t_{\mathrm{BDM}}$ & -0.3698 \\
\hline \multirow[t]{2}{*}{$F_{\mathrm{PSS}}$} & $2.7137[0.0683]$ & $F_{\mathrm{PSS}}$ & $2.0899[0.1022]$ & $F_{\mathrm{PSS}}$ & $1.9186[0.1272]$ & $F_{\mathrm{PSS}}$ & $3.1405[0.0450]$ \\
\hline & & $W_{L R}$ & 0.0082 [0.9278] & $W_{\mathrm{LR}}$ & $0.0180[0.8935]$ & & \\
\hline
\end{tabular}


Table 9: Estimation Results-NARDL-Information Technology

\begin{tabular}{|c|c|c|c|c|c|c|c|}
\hline \multicolumn{2}{|c|}{$\underline{\text { Symmetric ARDL }}$} & \multicolumn{2}{|c|}{$\frac{\text { NARDL with SR \& LR }}{\text { asymmetry }}$} & \multicolumn{2}{|c|}{ NARDL with LR asymmetry } & \multicolumn{2}{|c|}{ NARDL with SR asymmetry } \\
\hline Variable & Coefficients & Variable & Coefficients & Variable & Coefficients & Variable & Coefficients \\
\hline C & $0.0069(0.0646)$ & $\mathrm{C}$ & $0.2360 *(0.0994)$ & C & $0.2415 *(0.1006)$ & $\mathrm{C}$ & $-0.0131(0.0659)$ \\
\hline $\mathrm{RET}_{\mathrm{t}-1}$ & $-0.0015(0.0044)$ & $\mathrm{RET}_{\mathrm{t}-1}$ & $-0.0479 *(0.0210)$ & $\mathrm{RET}_{\mathrm{t}-1}$ & $-0.0500 *(0.0213)$ & $\mathrm{RET}_{\mathrm{t}-1}$ & $-0.0019(0.0044)$ \\
\hline$E P U_{t-1}$ & $-0.0007(0.0108)$ & $\mathrm{EPU}^{+}{ }_{\mathrm{t}-1}$ & $-0.0005(0.0113)$ & $E P U^{+} t-1$ & $-0.0198(0.0128)$ & $E P U_{t-1}$ & $0.0018(0.0111)$ \\
\hline$\triangle \mathrm{EPU}$ & $-0.1045^{*}(0.0372)$ & $\mathrm{EPU}_{\mathrm{t}-1}^{-}$ & $-0.0156(0.0134)$ & $E P U^{-}-1$ & $-0.0345 *(0.0150)$ & $\Delta \mathrm{EPU}_{\mathrm{t}-7}^{+}$ & $-0.1775 *(0.0807)$ \\
\hline \multirow[t]{9}{*}{$\Delta \mathrm{EPU}_{\mathrm{t}-9}$} & $-0.0785^{*}(0.0380)$ & $\Delta \mathrm{EPU}^{+}{ }_{\mathrm{t}-10}$ & $0.02111 *(0.1012)$ & $\triangle \mathrm{EPU}$ & $-0.1342 *(0.0428)$ & $\Delta \mathrm{EPU}^{+}{ }_{\mathrm{t}-8}$ & $0.3294 *(0.1002)$ \\
\hline & & $\Delta \mathrm{EPU}_{\mathrm{t}-8}^{-}$ & $-0.2618 *(0.1080)$ & $\Delta \mathrm{EPU}_{\mathrm{t}-2}$ & $0.0956 *(0.0476)$ & $\Delta \mathrm{EPU}^{+}{ }_{\mathrm{t}-8}$ & $-0.2437 *(0.0801)$ \\
\hline & & $\Delta E P U^{-}-11$ & $0.1876 *(0.0795)$ & $\Delta \mathrm{RET}_{\mathrm{t}-1}$ & $0.1287^{*}(0.0639)$ & & \\
\hline & & $\Delta \mathrm{RET}_{\mathrm{t}-1}$ & $0.1789 *(0.0640)$ & $\Delta \mathrm{EPU}^{+}{ }_{\mathrm{t}-8}$ & $0.1225 *(0.0519)$ & & \\
\hline & & $\Delta \mathrm{EPU}^{+}{ }_{\mathrm{t}-11}$ & $-0.2178 *(0.0870)$ & $\Delta \mathrm{EPU}^{+}{ }_{\mathrm{t}-9}$ & $-0.1267 *(0.0502)$ & & \\
\hline & & $\Delta \mathrm{EPU}_{\mathrm{t}-7}^{-}$ & $0.2451 *(0.1087)$ & & & & \\
\hline & & $\Delta \mathrm{EPU}^{+}{ }_{\mathrm{t}-8}$ & $0.4453 *(0.1068)$ & & & & \\
\hline & & $\Delta \mathrm{EPU}^{+}{ }_{\mathrm{t}-9}$ & $-0.3161 *(0.1012)$ & & & & \\
\hline & & $\Delta \mathrm{EPU}_{\mathrm{t}-7}^{+}$ & $-0.2554 *(0.0897)$ & & & & \\
\hline \multirow[t]{2}{*}{$\mathrm{L}_{E P U}$} & $-0.4666^{*}$ & $\mathrm{LEPU}^{+}$ & $-0.0104 *$ & $\mathrm{LEPU}^{+}$ & $-0.3960 *$ & $\mathrm{~L}_{\mathrm{EPU}}$ & $0.9474^{*}$ \\
\hline & & $\mathrm{LEPU}^{-}$ & $-0.3257^{*}$ & $\mathrm{LEPU}^{-}$ & $-0.6900 *$ & & \\
\hline $\mathrm{R}^{2}$ & 0.0438 & $\mathrm{R}^{2}$ & 0.1349 & $\mathrm{R}^{2}$ & 0.0952 & $\mathrm{R}^{2}$ & 0.0758 \\
\hline Adj. $R^{2}$ & 0.0283 & Adj. $R^{2}$ & 0.0911 & Adj. $R^{2}$ & 0.0654 & Adj. $R^{2}$ & 0.0532 \\
\hline $\mathrm{X}^{2}{ }_{\mathrm{BG}}$ & $1.858[0.1581]$ & $\mathrm{X}^{2}{ }_{\mathrm{BG}}$ & $1.1974[0.3038]$ & $X^{2} B G$ & $1.4431[0.2382]$ & $\mathrm{X}^{2} \mathrm{BG}$ & 3.2911 [0.0389] \\
\hline $\mathrm{X}^{2}{ }_{\mathrm{RR}}$ & $0.0111[0.9164]$ & $X^{2}{ }_{R R}$ & $2.7950[0.0959]$ & $X^{2}{ }_{R R}$ & $0.0183[0.8925]$ & $X^{2}{ }_{R R}$ & $3.5709[0.0600]$ \\
\hline$X^{2}{ }_{\mathrm{JB}}$ & $9.8696[0.0072]$ & $\mathrm{X}^{2} \mathrm{JB}$ & $13.1707[0.0014]$ & $\mathrm{X}^{2} \mathrm{JB}$ & $14.7077[0.0006]$ & $\mathrm{X}^{2} \mathrm{JB}$ & $4.0578[0.1314]$ \\
\hline$t_{\mathrm{BDM}}$ & -2.2845 & $t_{\mathrm{BDM}}$ & -2.2845 & $t_{\mathrm{BDM}}$ & -2.2845 & $t_{\mathrm{BDM}}$ & -2.2845 \\
\hline \multirow[t]{3}{*}{$F_{\mathrm{PSS}}$} & $0.1225[0.8847]$ & $F_{\text {PSS }}$ & $2.3611[0.0720]$ & $F_{\mathrm{PSS}}$ & $2.3611[0.0720]$ & $F_{\mathrm{PSS}}$ & $0.1008[0.9041]$ \\
\hline & & $W_{\mathrm{LR}}$ & $113.2448[0.0000]$ & $W_{\mathrm{LR}}$ & $119.4059[0.0000]$ & & \\
\hline & & $W_{S R}$ & $3.6215[0.0583]$ & & & $W_{S R}$ & $0.0481[0.8266]$ \\
\hline
\end{tabular}

Notes: Similar to Table 6

Table 10: Estimation Results-NARDL- Utilities

\begin{tabular}{|c|c|c|c|c|c|c|c|}
\hline \multicolumn{2}{|c|}{ Symmetric ARDL } & \multicolumn{2}{|c|}{$\frac{\text { NARDL with SR \& LR }}{\text { asymmetry }}$} & \multicolumn{2}{|c|}{$\underline{\text { NARDL with LR asymmetry }}$} & \multicolumn{2}{|c|}{ NARDL with SR asymmetry } \\
\hline Variable & Coefficients & Variable & Coefficients & Variable & Coefficients & Variable & Coefficients \\
\hline C & $0.0499(0.0441)$ & $\mathrm{C}$ & $0.1900 *(0.0798)$ & $\mathrm{C}$ & $0.1959 *(0.0775)$ & $\mathrm{C}$ & $0.0521(0.0438)$ \\
\hline $\mathrm{RET}_{\mathrm{t}-1}$ & $-0.0110(0.0067)$ & $\mathrm{RET}_{\mathrm{t}-1}$ & $-0.0402 *(0.0170)$ & $\mathrm{RET}_{\mathrm{t}-1}$ & $-0.0414 *(0.0165)$ & $\mathrm{RET}_{\mathrm{t}-1}$ & $-0.0112 *(0.0068)$ \\
\hline$E P U_{t-1}$ & $0.0011(0.0044)$ & $E P U^{+}{ }_{t-1}$ & $0.0041(0.0048)$ & $\mathrm{EPU}^{+} \mathrm{t}-1$ & $0.0045(0.0047)$ & $E P U_{t-1}$ & $0.0006(0.0044)$ \\
\hline$\Delta \mathrm{RET}_{\mathrm{t}-1}$ & $0.2524 *(0.0602)$ & $E P U^{-} t-1$ & $0.0015(0.0044)$ & $E P U^{-}{ }_{t-1}$ & $0.0017(0.0044)$ & $\Delta \mathrm{RET}_{\mathrm{t}-1}$ & $0.2518 *(0.0603)$ \\
\hline$\Delta \mathrm{EPU}_{\mathrm{t}-7}$ & $-0.0525 *(0.0216)$ & $\Delta \mathrm{RET}_{\mathrm{t}-1}$ & $0.2692 *(0.0607)$ & $\Delta \mathrm{RET}_{\mathrm{t}-1}$ & $0.2706 *(0.0605)$ & $\Delta \mathrm{EPU}^{+}{ }_{\mathrm{t}-8}$ & $0.1103 *(0.0337)$ \\
\hline \multirow[t]{2}{*}{$\Delta \mathrm{EPU}_{\mathrm{t}-8}$} & $0.0733 *(0.0212)$ & $\Delta \mathrm{EPU}^{+}{ }_{\mathrm{t}-7}$ & $-0.0850 *(0.0342)$ & $\Delta \mathrm{EPU}^{+}{ }_{\mathrm{t}-7}$ & $-0.0570 *(0.0216)$ & $\Delta \mathrm{EPU}^{+}{ }_{\mathrm{t}-7}$ & $-0.0768 *(0.0340)$ \\
\hline & & $\Delta \mathrm{EPU}^{+}{ }_{\mathrm{t}-8}$ & $0.1015 *(0.0339)$ & $\Delta \mathrm{EPU}^{+}{ }_{\mathrm{t}-8}$ & $0.0697 *(0.0211)$ & & \\
\hline \multirow[t]{2}{*}{ LEPU } & $0.1000^{*}$ & $\mathrm{LEPU}^{+}$ & $0.1020^{*}$ & $\mathrm{LEPU}^{+}$ & $0.1090^{*}$ & $\mathrm{~L}_{\mathrm{EPU}}$ & $0.0538^{*}$ \\
\hline & & $\mathrm{LEPU}^{-}$ & $0.0373^{*}$ & $\mathrm{LEPU}^{-}$ & 0.0410 & & \\
\hline $\mathrm{R}^{2}$ & 0.1245 & $\mathrm{R}^{2}$ & 0.1322 & $\mathrm{R}^{2}$ & 0.1386 & $\mathrm{R}^{2}$ & 0.1200 \\
\hline Adj. $R^{2}$ & 0.1068 & Adj. $R^{2}$ & 0.1114 & Adj. $R^{2}$ & 0.1176 & Adj. $R^{2}$ & 0.1022 \\
\hline $\mathrm{X}^{2} \mathrm{BG}$ & 1.9023 [0.1514] & $X^{2} B G$ & $1.5701[0.2101]$ & $X^{2}{ }_{B G}$ & 1.5202 [0.2207] & $\mathrm{X}^{2}{ }_{\mathrm{BG}}$ & $2.0993[0.1247]$ \\
\hline$X^{2}{ }_{R R}$ & $0.9224[0.3378]$ & $X^{2}{ }_{R R}$ & $0.5955[0.4410]$ & $X^{2}{ }_{R R}$ & 0.9934 [0.3199] & $X^{2}{ }_{R R}$ & $0.3923[0.5317]$ \\
\hline$X^{2}{ }_{J B}$ & $6.5188[0.0384]$ & $\mathrm{X}^{2}{ }_{\mathrm{JB}}$ & $7.4835[0.0237]$ & $\mathrm{X}^{2} \mathrm{JB}$ & $8.4962[0.0143]$ & $\mathrm{X}^{2} \mathrm{JB}$ & $5.4424[0.0658]$ \\
\hline
\end{tabular}




\begin{tabular}{lclclccc}
$t_{\mathrm{BDM}}$ & -2.3615 & $t_{\mathrm{BDM}}$ & -2.3615 & $t_{\mathrm{BDM}}$ & -2.3615 & $t_{\mathrm{BDM}}$ & -2.3615 \\
$F_{\mathrm{PSS}}$ & $1.6680[0.1907]$ & $F_{\mathrm{PSS}}$ & $2.2411[0.0841]$ & $F_{\mathrm{PSS}}$ & $2.4706[0.0624]$ & $F_{\mathrm{PSS}}$ & $1.6218[0.1996]$ \\
& & $\mathrm{W}_{\mathrm{LR}}$ & $19.8752[0.0000]$ & $\mathrm{W}_{\mathrm{LR}}$ & $22.8793[0.0000]$ & & \\
& & $\mathrm{W}_{\mathrm{SR}}$ & $0.3543[0.5523]$ & & & $\mathrm{W}_{\mathrm{SR}}$ & $1.6038[0.2066]$ \\
\hline
\end{tabular}

Notes: Similar to Table 6

Table 11: Estimation Results-NARDL-Materials

\begin{tabular}{|c|c|c|c|c|c|c|c|}
\hline \multicolumn{2}{|c|}{ Symmetric ARDL } & \multicolumn{2}{|c|}{$\frac{\text { NARDL with SR \& LR }}{\text { asymmetry }}$} & \multicolumn{2}{|c|}{ NARDL with LR asymmetry } & \multicolumn{2}{|c|}{$\underline{\text { NARDL with SR asymmetry }}$} \\
\hline Variable & Coefficients & Variable & Coefficients & Variable & Coefficients & Variable & Coefficients \\
\hline $\mathrm{C}$ & $0.1340 *(0.0710)$ & C & $0.2271 * 0.0734)$ & $\mathrm{C}$ & $0.2259 *(0.0764)$ & C & $0.1529 *(0.0714)$ \\
\hline $\mathrm{RET}_{\mathrm{t}-1}$ & $-0.0242 * *(0.0120)$ & $\mathrm{RET}_{\mathrm{t}-1}$ & $-0.0472 *(0.0154)$ & $\mathrm{RET}_{\mathrm{t}-1}$ & $-0.0469 *(0.0160)$ & $\mathrm{RET}_{\mathrm{t}-1}$ & $-0.0262 *(0.0119)$ \\
\hline $\mathrm{EPU}_{\mathrm{t}-1}$ & $-0.0030(0.0060)$ & $\mathrm{EPU}^{+}{ }_{\mathrm{t}-1}$ & $-0.0001(0.0067)$ & $\mathrm{EPU}^{+}{ }_{\mathrm{t}-1}$ & $0.0054(0.0070)$ & $E P U_{t-1}$ & $-0.0052(0.0063)$ \\
\hline$\Delta \mathrm{RET}_{\mathrm{t}-1}$ & $0.2450 *(0.0608)$ & $E P U^{-}-1$ & $-0.0020(0.0064)$ & $E P U^{-}-1$ & $0.0033(0.0067)$ & $\Delta \mathrm{RET}_{\mathrm{t}-1}$ & $0.2478 *(0.0594)$ \\
\hline \multirow[t]{4}{*}{$\Delta \mathrm{RET}_{\mathrm{t}-12}$} & $-0.1513 *(0.0612)$ & $\Delta \mathrm{RET}_{\mathrm{t}-1}$ & $0.2614 *(0.0596)$ & $\Delta \mathrm{RET}_{\mathrm{t}-1}$ & $0.2591 * *(0.0604)$ & $\Delta \mathrm{EPU}^{+}{ }_{\mathrm{t}-8}$ & $0.1800 *(0.0492)$ \\
\hline & & $\Delta \mathrm{EPU}^{+}{ }_{\mathrm{t}-8}$ & $0.1823 *(0.0492)$ & $\Delta \mathrm{EPU}^{+}{ }_{\mathrm{t}-11}$ & $-0.0516 *(0.0243)$ & $\Delta \mathrm{EPU}^{+}{ }_{\mathrm{t}-\mathrm{7}}$ & $-0.1323 *(0.0495)$ \\
\hline & & $\Delta \mathrm{EPU}^{+} \mathrm{t}-7$ & $-0.1427 *(0.0496)$ & $\Delta \mathrm{EPU}^{+}{ }_{\mathrm{t}-8}$ & $0.1055 *(0.0329)$ & $\Delta \mathrm{RET}_{\mathrm{t}-12}$ & $-0.1370 *(0.0599)$ \\
\hline & & & & $\Delta \mathrm{EPU}^{+}{ }_{\mathrm{t}-7}$ & $-0.0983 *(0.0338)$ & & \\
\hline \multirow[t]{2}{*}{$\mathrm{L}_{\text {EPU }}$} & $-0.1240 *$ & $\mathrm{LEPU}^{+}$ & $-0.0021 *$ & $\mathrm{LEPU}^{+}$ & $0.1151^{*}$ & $\mathrm{~L}_{\text {EPU }}$ & $-0.1985^{*}$ \\
\hline & & $\mathrm{LEPU}^{-}$ & $-0.0424^{*}$ & $\mathrm{LEPU}^{-}$ & $0.0704^{*}$ & & \\
\hline $\mathrm{R}^{2}$ & 0.0986 & $R^{2}$ & 0.1408 & $\mathrm{R}^{2}$ & 0.1355 & $R^{2}$ & 0.1459 \\
\hline Adj. $R^{2}$ & 0.0838 & Adj. $R^{2}$ & 0.1199 & Adj. $R^{2}$ & 0.1105 & Adj. $R^{2}$ & 0.1248 \\
\hline $\mathrm{X}^{2}{ }_{\mathrm{BG}}$ & $0.5730[0.5646]$ & $\mathrm{X}^{2}{ }_{\mathrm{BG}}$ & 0.3703 [0.6909] & $X^{2}{ }_{B G}$ & 0.3815 [0.3863] & $\mathrm{X}^{2}{ }_{\mathrm{BG}}$ & $0.6299[0.5335]$ \\
\hline$X^{2}{ }_{R R}$ & $1.2262[0.2692]$ & $X^{2}{ }_{R R}$ & $5.6378[0.0183]$ & $X^{2}{ }_{R R}$ & $2.9774[0.0857]$ & $X^{2}{ }_{R R}$ & $5.4145[0.0208]$ \\
\hline$X^{2} J B$ & $21.0687[0.0000]$ & $X^{2} J B$ & 8.7007 [0.0129] & $\mathrm{X}^{2} \mathrm{JB}$ & $5.1806[0.0750]$ & $X^{2} J B$ & $7.1705[0.0277]$ \\
\hline$t_{\mathrm{BDM}}$ & -3.0680 & $t_{\mathrm{BDM}}$ & -3.0680 & $t_{\mathrm{BDM}}$ & -3.0680 & $t_{\mathrm{BDM}}$ & -3.0680 \\
\hline \multirow[t]{3}{*}{$F_{\mathrm{PSS}}$} & $2.0127[0.1358]$ & $F_{\mathrm{PSS}}$ & $3.2679[0.0220]$ & $F_{\text {PSS }}$ & $3.0361[0.0298]$ & $F_{\mathrm{PSS}}$ & $4.2645[0.0874]$ \\
\hline & & $W_{L R}$ & $4.9314[0.0273]$ & $W_{L R}$ & $6.3622[0.0123]$ & & \\
\hline & & $\mathrm{W}_{\mathrm{SR}}$ & $1.0287[0.3115]$ & & & $W_{S R}$ & $1.5167[0.2193]$ \\
\hline
\end{tabular}

Table 12: Estimation Results-NARDL-Telecom

\begin{tabular}{|c|c|c|c|c|c|c|c|}
\hline \multicolumn{2}{|c|}{$\underline{\text { Symmetric ARDL }}$} & \multicolumn{2}{|c|}{$\frac{\text { NARDL with SR \& LR }}{\text { asymmetry }}$} & \multicolumn{2}{|c|}{$\underline{\text { NARDL with LR asymmetry }}$} & \multicolumn{2}{|c|}{ NARDL with SR asymmetry } \\
\hline Variable & Coefficients & Variable & Coefficients & Variable & Coefficients & Variable & Coefficients \\
\hline C & $-0.0157(0.0413)$ & $\mathrm{C}$ & $0.1427 *(0.0564)$ & $\mathrm{C}$ & $0.1184 *(0.0558)$ & $\mathrm{C}$ & $-0.0208(0.0389)$ \\
\hline $\mathrm{RET}_{\mathrm{t}-1}$ & $0.0020(0.0036)$ & RET $_{t-1}$ & $-0.0304 *(0.0123)$ & $\mathrm{RET}_{\mathrm{t}-1}$ & $-0.0254 *(0.0122)$ & RET $_{t-1}$ & $0.0048(0.0036)$ \\
\hline$E P U_{t-1}$ & $0.0004(0.0066)$ & $\mathrm{EPU}^{+} \mathrm{t}-1$ & $0.0029(0.0071)$ & $\mathrm{EPU}^{+} \mathrm{t}-1$ & $0.0072(0.0067)$ & $E P U_{t-1}$ & $0.0004(0.0062)$ \\
\hline$\Delta \mathrm{RET}_{\mathrm{t}-1}$ & $0.1481 *(0.0628)$ & $\mathrm{EPU}_{\mathrm{t}-1}^{-}$ & $-0.0036(0.0071)$ & $E P U^{-}-1$ & $0.0015(0.0067)$ & $\Delta \mathrm{RET}_{\mathrm{t}-1}$ & $0.1399 *(0.0627)$ \\
\hline$\Delta \mathrm{EPU}_{\mathrm{t}-2}$ & $0.0706 *(0.0307)$ & $\Delta \mathrm{RET}_{\mathrm{t}-1}$ & $0.1563 *(0.0623)$ & $\Delta \mathrm{RET}_{\mathrm{t}-1}$ & $0.1560 *(0.0625)$ & $\Delta \mathrm{EPU}^{+}{ }_{\mathrm{t}-3}$ & $-0.1165 *(0.0501)$ \\
\hline \multirow[t]{6}{*}{$\triangle \mathrm{EPU}_{\mathrm{t}-3}$} & $-0.0624 *(0.0325)$ & $\Delta \mathrm{RET}_{\mathrm{t}-4}$ & $0.1429 *(0.0633)$ & $\Delta \mathrm{EPU}^{+}{ }_{\mathrm{t}-2}$ & $0.0682 *(0.0305)$ & $\Delta \mathrm{EPU}^{+}{ }_{\mathrm{t}-2}$ & $0.1321 *(0.0485)$ \\
\hline & & $\Delta \mathrm{EPU}^{+}{ }_{\mathrm{t}-3}$ & $-0.1388 *(0.0500)$ & $\Delta \mathrm{EPU}^{+}{ }_{\mathrm{t}-3}$ & $-0.0639 *(0.0322)$ & & \\
\hline & & $\Delta \mathrm{EPU}_{\mathrm{t}-6}^{-}$ & $-0.1533 *(0.0718)$ & & & & \\
\hline & & $\Delta \mathrm{EPU}_{\mathrm{t}-5}^{-}$ & $0.1290 *(0.0592)$ & & & & \\
\hline & & $\Delta \mathrm{EPU}^{+}{ }_{\mathrm{t}-2}$ & $0.1515 *(0.0492)$ & & & & \\
\hline & & $\Delta \mathrm{EPU}^{+}{ }_{\mathrm{t}-7}$ & $0.1121 *(0.0582)$ & & & & \\
\hline \multirow[t]{2}{*}{ LePU } & $0.2000^{*}$ & $\mathrm{LEPU}^{+}$ & $0.0954^{*}$ & $\mathrm{LEPU}^{+}$ & $0.2835^{*}$ & $\mathrm{~L}_{\text {EPU }}$ & 0.0833 \\
\hline & & $\mathrm{L}_{E P U^{-}}{ }^{-}$ & $-0.1184 *$ & $\mathrm{LEPU}^{-}$ & $0.0591 *$ & & \\
\hline $\mathrm{R}^{2}$ & 0.0418 & $\mathrm{R}^{2}$ & 0.1069 & $\mathrm{R}^{2}$ & 0.0598 & $\mathrm{R}^{2}$ & 0.0497 \\
\hline Adj. $R^{2}$ & 0.0228 & Adj. $R^{2}$ & 0.0701 & Adj. $R^{2}$ & 0.0373 & Adj. $R^{2}$ & 0.0308 \\
\hline$X^{2}{ }_{B G}$ & 0.4729 [0.6237] & $X^{2}{ }_{B G}$ & 0.2034 [0.8161] & $X^{2}{ }_{B G}$ & 0.3092 [0.7343] & $X^{2}{ }_{B G}$ & $0.2981[0.7425]$ \\
\hline$X^{2}{ }_{R R}$ & $0.0752[0.7841]$ & $\mathrm{X}^{2}{ }_{\mathrm{RR}}$ & $0.0366[0.484]$ & $X^{2}{ }_{R R}$ & $0.0447[0.8327]$ & $X^{2}{ }_{R R}$ & $4.5491[0.0339]$ \\
\hline
\end{tabular}




\begin{tabular}{lclclccc}
$\mathrm{X}^{2}{ }_{\mathrm{JB}}$ & $1.3723[0.5035]$ & $\mathrm{X}_{\mathrm{JB}}$ & $0.9395[0.6252]$ & $\mathrm{X}^{2}{ }_{\mathrm{JB}}$ & $2.5334[0.2818]$ & $\mathrm{X}^{2}{ }_{\mathrm{JB}}$ & $1.2550[0.5340]$ \\
$t_{\mathrm{BDM}}$ & -2.4741 & $t_{\mathrm{BDM}}$ & -2.4741 & $t_{\mathrm{BDM}}$ & -2.4741 & $t_{\mathrm{BDM}}$ & -2.4741 \\
$F_{\mathrm{PSS}}$ & $0.2064[0.8136]$ & $F_{\mathrm{PSS}}$ & $2.0984[0.1010]$ & $F_{\mathrm{PSS}}$ & $1.7411[0.1591]$ & $F_{\mathrm{PSS}}$ & $0.3206[0.7260]$ \\
& & $\mathrm{W}_{\mathrm{LR}}$ & $66.0966[0.0000]$ & $\mathrm{W}_{\mathrm{LR}}$ & $49.6219[0.0000]$ & & \\
& & & & & $W_{\mathrm{SR}}$ & $0.1791[0.6725]$ \\
\hline
\end{tabular}

Notes: Similar to Table 6

Table 13: Estimation Results-NARDL-Industrials

\begin{tabular}{|c|c|c|c|c|c|c|c|}
\hline \multicolumn{2}{|c|}{ Symmetric ARDL } & \multicolumn{2}{|c|}{$\frac{\text { NARDL with SR \& LR }}{\text { asymmetry }}$} & \multicolumn{2}{|c|}{ NARDL with LR asymmetry } & \multicolumn{2}{|c|}{ NARDL with SR asymmetry } \\
\hline Variable & Coefficients & Variable & Coefficients & Variable & Coefficients & Variable & Coefficients \\
\hline $\mathrm{C}$ & $0.0610(0.0466)$ & $\mathrm{C}$ & $0.1828 *(0.0836)$ & C & $0.1928 *(0.0855)$ & $\mathrm{C}$ & $0.0726(0.0462)$ \\
\hline RET $_{\mathrm{t}-1}$ & $-0.0084(0.0051)$ & $\mathrm{RET}_{\mathrm{t}-1}$ & $-0.0370 *(0.0175)$ & $\mathrm{RET}_{\mathrm{t}-1}$ & $-0.0392 *(0.0179)$ & $\mathrm{RET}_{\mathrm{t}-1}$ & $-0.0092 * *(0.0051)$ \\
\hline$E P U_{t-1}$ & $-0.0030(0.0064)$ & $\mathrm{EPU}^{+} \mathrm{t}-1$ & $0.0002(0.0065)$ & $\mathrm{EPU}^{+} \mathrm{t}-1$ & $0.0065(0.0072)$ & $E P U_{t-1}$ & $-0.0048(0.0063)$ \\
\hline$\Delta \mathrm{RET}_{\mathrm{t}-12}$ & $-0.1542 *(0.0641)$ & $\mathrm{EPU}^{-} \mathrm{t}-1$ & $-0.0045 *(0.0063)$ & $E P U^{-}-1$ & $0.0012(0.0068)$ & $\Delta \mathrm{RET}_{\mathrm{t}-12}$ & $-0.1583 *(0.0630)$ \\
\hline$\Delta \mathrm{RET}_{\mathrm{t}-1}$ & $0.1358 *(0.0625)$ & $\Delta \mathrm{RET}_{\mathrm{t}-1}$ & $0.1786 *(0.0631)$ & $\Delta \mathrm{RET}_{\mathrm{t}-1}$ & $0.1583 *(0.0624)$ & $\Delta \mathrm{EPU}^{+}{ }_{\mathrm{t}-8}$ & $0.1785 *(0.0465)$ \\
\hline$\Delta \mathrm{EPU}_{\mathrm{t}-8}$ & $0.0750 *(0.0298)$ & $\Delta \mathrm{EPU}^{+} \mathrm{t}-8$ & $0.2467 *(0.0585)$ & $\Delta \mathrm{RET}_{\mathrm{t}-12}$ & $-0.1315 *(0.0643)$ & $\Delta \mathrm{EPU}^{+}{ }_{\mathrm{t}-7}$ & $-0.1366 *(0.0470)$ \\
\hline \multirow[t]{3}{*}{$\Delta \mathrm{EPU}_{\mathrm{t}-7}$} & $-0.0614 *(0.0305)$ & $\Delta \mathrm{RET}_{\mathrm{t}-12}$ & $-0.1359 *(0.0632)$ & $\Delta \mathrm{EPU}_{\mathrm{t}-6}$ & $-0.0721 *(0.0271)$ & $\Delta \mathrm{RET}_{\mathrm{t}-1}$ & $0.1357 *(0.0615)$ \\
\hline & & $\Delta \mathrm{EPU}^{+}{ }_{\mathrm{t}-9}$ & $-0.0942 *(0.0476)$ & $\Delta \mathrm{EPU}_{\mathrm{t}-8}$ & $0.0595 *(0.0246)$ & & \\
\hline & & & & $\Delta \mathrm{EPU}_{\mathrm{t}-11}$ & $-0.0476 *(0.0235)$ & & \\
\hline \multirow[t]{2}{*}{ LEPU } & $-0.3571 *$ & $\mathrm{LEPU}^{+}$ & $0.0054^{*}$ & $\mathrm{LEPU}^{+}$ & $0.1658 *$ & LEPU & $-0.5217^{*}$ \\
\hline & & $L_{E P U}{ }^{-}$ & $-0.1216^{*}$ & $\mathrm{LEPU}^{-}$ & $0.0306^{*}$ & & \\
\hline $\mathrm{R}^{2}$ & 0.0760 & $\mathrm{R}^{2}$ & 0.1304 & $\mathrm{R}^{2}$ & 0.1008 & $\mathrm{R}^{2}$ & 0.1059 \\
\hline Adj. $R^{2}$ & 0.0531 & Adj. $R^{2}$ & 0.1014 & Adj. $R^{2}$ & 0.0709 & Adj. $R^{2}$ & 0.0 .837 \\
\hline $\mathrm{X}^{2} \mathrm{BG}$ & $0.5485[0.5785]$ & $\mathrm{X}^{2}{ }_{\mathrm{BG}}$ & $0.4271[0.6529]$ & $\mathrm{X}^{2} \mathrm{BG}$ & 0.1149 [0.8915] & $\mathrm{X}^{2}{ }_{\mathrm{BG}}$ & $1.1528[0.3175]$ \\
\hline $\mathrm{X}^{2}{ }_{\mathrm{RR}}$ & $0.5325[0.4663]$ & $\mathrm{X}^{2}{ }_{\mathrm{RR}}$ & $5.0734[0.0252]$ & $\mathrm{X}^{2}{ }_{\mathrm{RR}}$ & $0.5968[0.4406]$ & $\mathrm{X}^{2}{ }_{\mathrm{RR}}$ & $5.9090[0.0158]$ \\
\hline$X^{2} \mathrm{JB}$ & $28.8870[0.0000]$ & $X^{2}{ }_{J B}$ & $26.6205[0.0000]$ & $\mathrm{X}^{2} \mathrm{JB}$ & $46.6590[0.0000]$ & $X^{2} J B$ & $12.3574[0.0000]$ \\
\hline$t_{\mathrm{BDM}}$ & -2.1218 & $t_{\mathrm{BDM}}$ & -2.1218 & $t_{\mathrm{BDM}}$ & -2.1218 & $t_{\mathrm{BDM}}$ & -2.1218 \\
\hline \multirow[t]{3}{*}{$F_{\mathrm{PSS}}$} & $1.3622[0.2581]$ & $F_{\text {PSS }}$ & $1.9007[0.1301]$ & $F_{\mathrm{PSS}}$ & $2.0769[0.1039]$ & $F_{\mathrm{PSS}}$ & $1.6545[0.1933]$ \\
\hline & & $W_{L R}$ & $28.1824[0.0000]$ & $W_{L R}$ & $39.4969[0.0000]$ & & \\
\hline & & $W_{S R}$ & $1.5990[0.2073]$ & & & $W_{S R}$ & $1.2811[0.2588]$ \\
\hline
\end{tabular}

Notes: Similar to Table 6

Table 14: Estimation Results-NARDL-Financials

\begin{tabular}{|c|c|c|c|c|c|c|c|}
\hline \multicolumn{2}{|c|}{ Symmetric ARDL } & \multicolumn{2}{|c|}{$\frac{\text { NARDL with SR \& LR }}{\text { asymmetry }}$} & \multicolumn{2}{|c|}{ NARDL with LR asymmetry } & \multicolumn{2}{|c|}{ NARDL with SR asymmetry } \\
\hline Variable & Coefficients & Variable & Coefficients & Variable & Coefficients & Variable & Coefficients \\
\hline C & $0.0620(0.0618)$ & $\mathrm{C}$ & $0.4630 *(0.1303)$ & $\mathrm{C}$ & $0.4439 *(0.1268)$ & $\mathrm{C}$ & $0.0394(0.0641)$ \\
\hline RET $_{\mathrm{t}-1}$ & $-0.0066(0.0050)$ & $\mathrm{RET}_{\mathrm{t}-1}$ & $-0.0951 *(0.0272)$ & $\mathrm{RET}_{\mathrm{t}-1}$ & $-0.0914 *(0.0265)$ & $\mathrm{RET}_{\mathrm{t}-1}$ & $-0.0057(0.0049)$ \\
\hline$E P U_{t-1}$ & $-0.0041(0.0099)$ & $\mathrm{EPU}^{+}{ }_{\mathrm{t}-1}$ & $0.0089(0.0107)$ & $\mathrm{EPU}^{+}{ }_{\mathrm{t}-1}$ & $0.0086(0.0099)$ & $E P U_{t-1}$ & $-0.0003(0.0106)$ \\
\hline \multirow[t]{5}{*}{$\Delta \mathrm{RET}_{\mathrm{t}-12}$} & $-0.1343 *(0.0657)$ & $E P U^{-}-1$ & $-0.0153(0.0112)$ & $E P U^{-}-1$ & $-0.0149(0.0102)$ & $\Delta \mathrm{EPU}_{\mathrm{t}-7}$ & $-0.1842 *(0.0789)$ \\
\hline & & $\Delta \mathrm{RET}_{\mathrm{t}-4}$ & $0.1287 *(0.0624)$ & $\Delta \mathrm{RET}_{\mathrm{t}-4}$ & $0.1281 *(0.0626)$ & $\Delta \mathrm{EPU}^{+}{ }_{\mathrm{t}-9}$ & $-0.1817^{*}(0.0784)$ \\
\hline & & $\Delta \mathrm{EPU}^{+}{ }_{\mathrm{t}-9}$ & $-0.1612 *(0.0769)$ & & & $\Delta \mathrm{EPU}^{+}{ }_{\mathrm{t}-8}$ & $0.3413 *(0.0981)$ \\
\hline & & $\Delta E P U^{-}{ }_{t-8}$ & $0.3169 *(0.0962)$ & & & & \\
\hline & & $\Delta \mathrm{EPU}^{+}{ }_{\mathrm{t}-7}$ & $-0.1814 *(0.0772)$ & & & & \\
\hline \multirow[t]{2}{*}{$\mathrm{L}_{\text {EPU }}$} & $-0.6212^{*}$ & $\mathrm{LEPU}^{+}$ & $0.0936^{*}$ & $\mathrm{LEPU}^{+}$ & $0.0941^{*}$ & LEPU & $-0.0526^{*}$ \\
\hline & & $\mathrm{LEPU}^{-}$ & $-0.1609 *$ & $L_{E P U} U^{-}$ & $-0.1631^{*}$ & & \\
\hline$R^{2}$ & 0.0225 & $R^{2}$ & 0.1034 & $R^{2}$ & 0.0554 & $\mathrm{R}^{2}$ & 0.0548 \\
\hline Adj. $R^{2}$ & 0.0105 & $\operatorname{Adj} . R^{2}$ & 0.0777 & $\operatorname{Adj} . R^{2}$ & 0.0404 & Adj. $R^{2}$ & 0.0356 \\
\hline $\mathrm{X}^{2}{ }_{\mathrm{BG}}$ & $1.6131[0.2014]$ & $X^{2} B G$ & 2.2605 [0.1065] & $X^{2} B G$ & $1.3446[0.2625]$ & $X^{2} B G$ & $2.4372[0.0895]$ \\
\hline$X^{2}{ }_{R R}$ & $3.8753[0.0501]$ & $X^{2}{ }_{R R}$ & $0.2437[0.6220]$ & $X^{2}{ }_{R R}$ & $1.5403[0.2157]$ & $X^{2}{ }_{R R}$ & $0.0987[0.7536]$ \\
\hline
\end{tabular}




\begin{tabular}{|c|c|c|c|c|c|c|c|}
\hline$X^{2}{ }_{J B}$ & $34.8783[0.0000]$ & $\mathrm{X}^{2} \mathrm{JB}$ & $37.1008[0.0000]$ & $\mathrm{X}^{2} \mathrm{JB}$ & $46.2274[0.0000]$ & $\mathrm{X}_{\mathrm{JB}}^{2}$ & $36.7030[0.0000]$ \\
\hline$t_{\mathrm{BDM}}$ & -3.4920 & $t_{\mathrm{BDM}}$ & -3.4920 & $t_{\mathrm{BDM}}$ & -3.4920 & $t_{\mathrm{BDM}}$ & -3.4920 \\
\hline \multirow[t]{3}{*}{$F_{\mathrm{PSS}}$} & $0.9021[0.4071]$ & $F_{\mathrm{PSS}}$ & $0.9021[0.4071]$ & $F_{\mathrm{PSS}}$ & $4.1461[0.0068]$ & $F_{\mathrm{PSS}}$ & 0.8470 [0.4299] \\
\hline & & $W_{L R}$ & $353.1522[0.0000]$ & $W_{L R}$ & $361.8926[0.0000]$ & & \\
\hline & & $\mathrm{W}_{\mathrm{SR}}$ & 0.1519 [0.6971] & & & $W_{S R}$ & $4.1298[0.7001]$ \\
\hline
\end{tabular}

Notes: Similar to Table 6

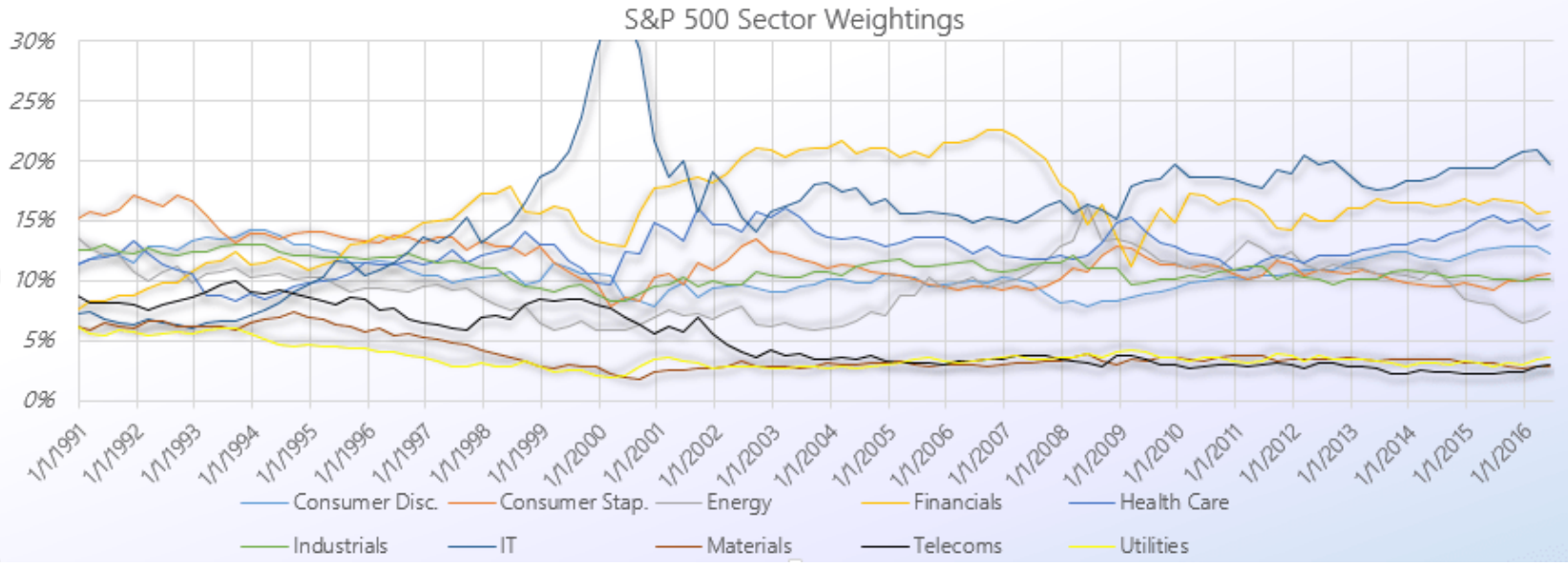

Figure 1: US sector based weightings of S\&P 500 


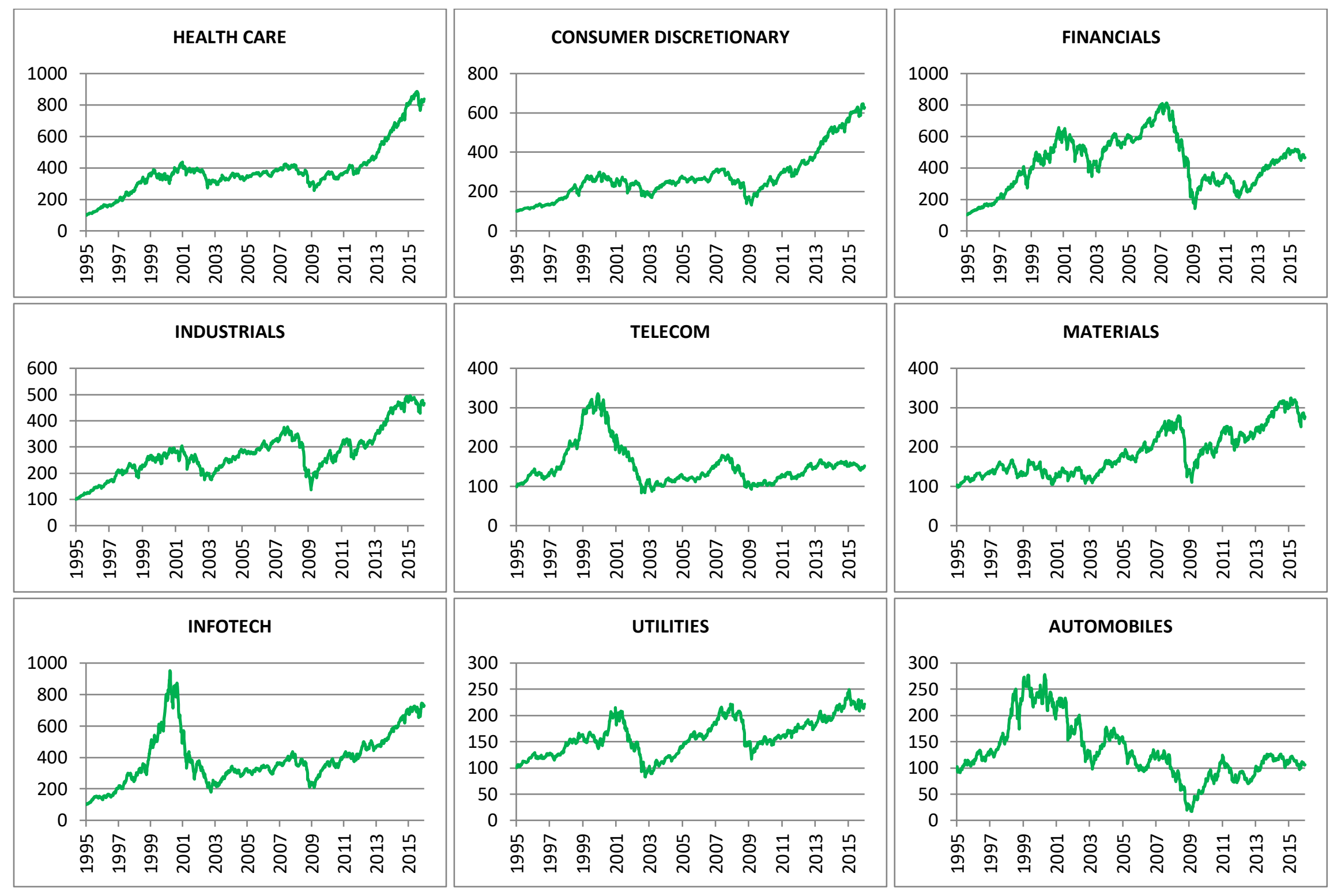

Figure 2 Time trend for major US sector monthly returns 
Panel A: Automobiles

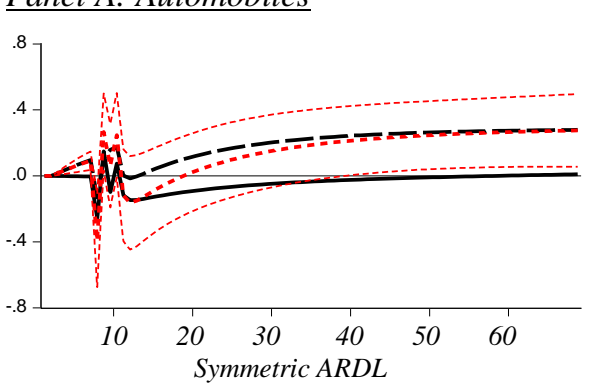

Panel B: Consumer Discretionary

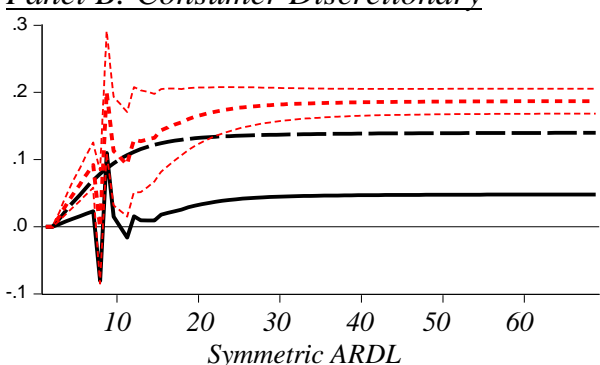

\section{Panel C: Healthcare}

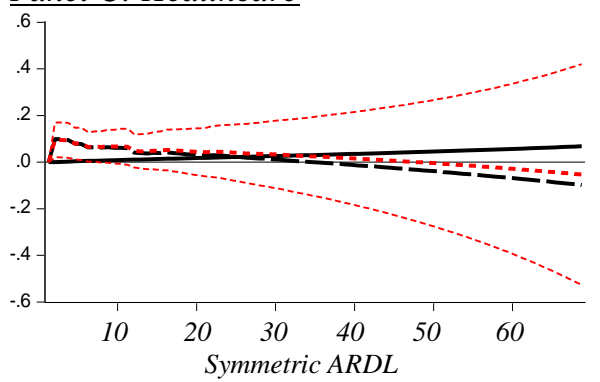

Panel D: Information Technology

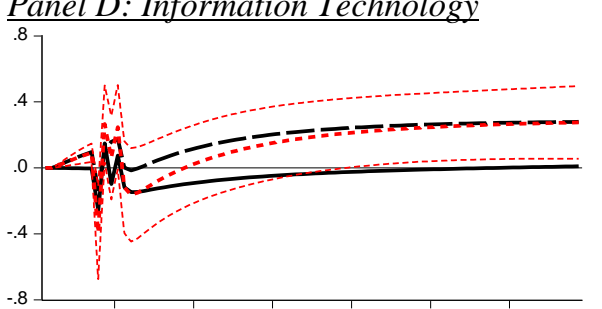

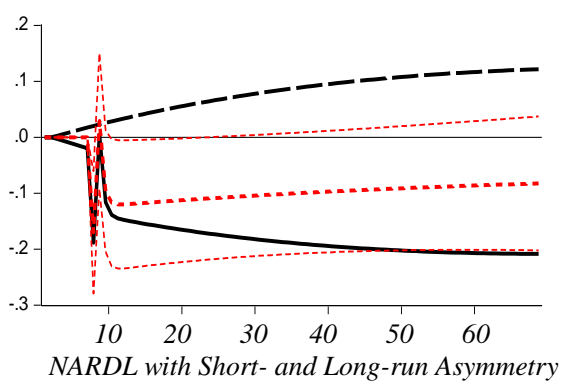
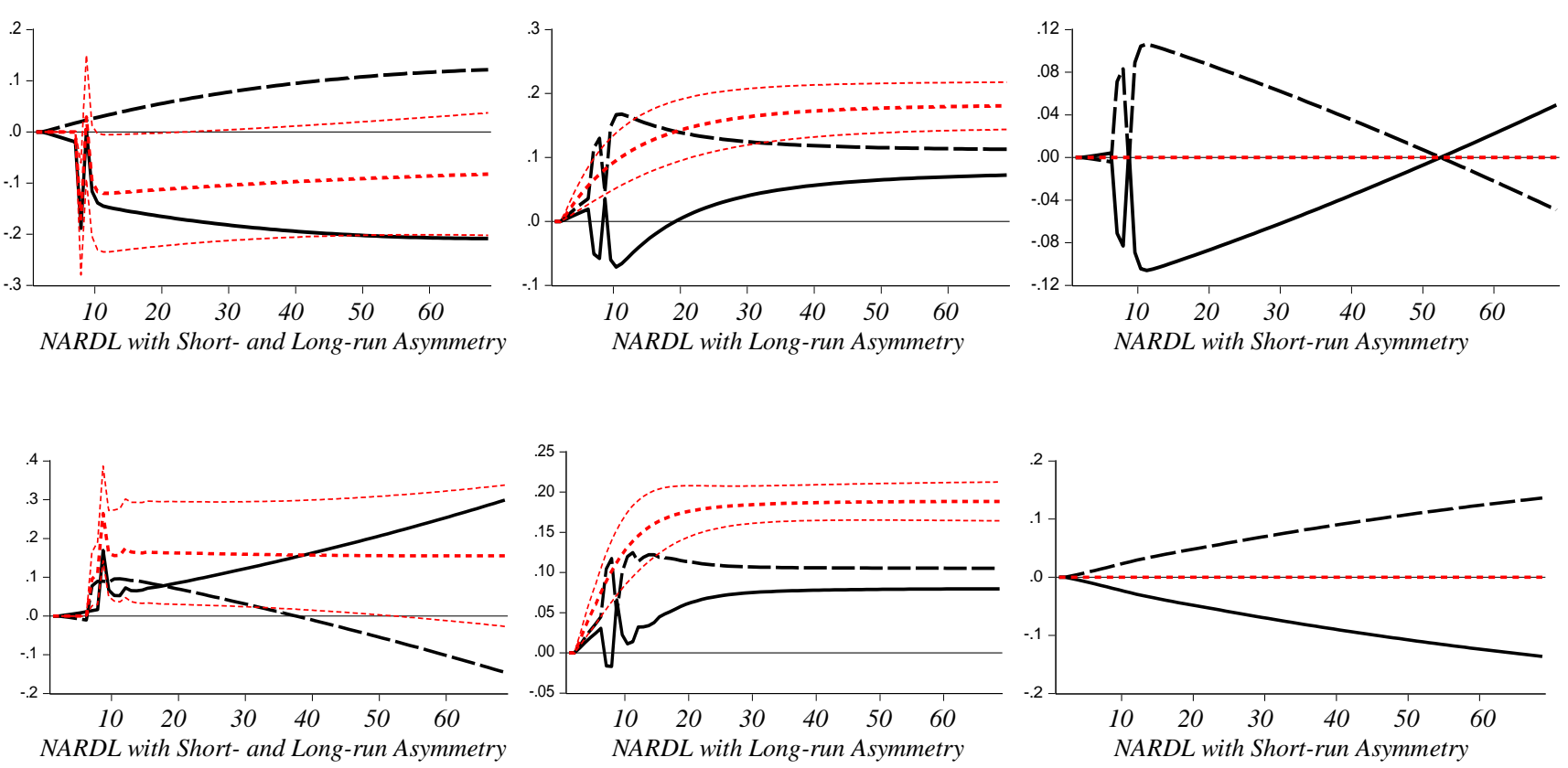

NARDL with Short-run Asymmetry
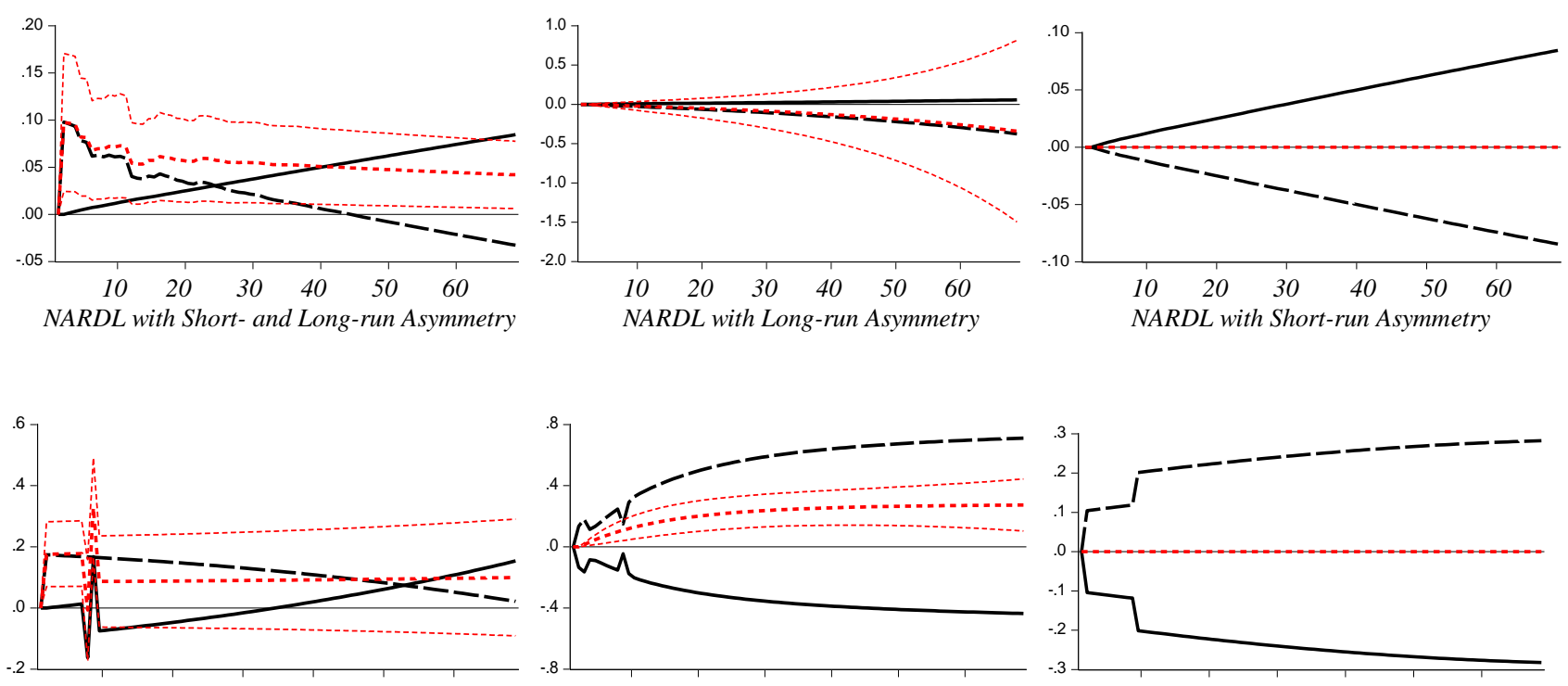
$\begin{array}{llllll}10 & 20 & 30 & 40 & 50 & 60\end{array}$ Symmetric ARDL
60

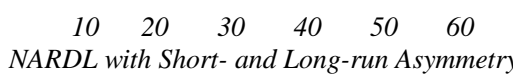

$\begin{array}{llllll}10 & 20 & 30 & 40 & 50 & 60\end{array}$

NARDL with Long-run Asymmetry $\begin{array}{lrrrrr}10 & 20 & 30 & 40 & 50 & 60\end{array}$

NARDL with Short-run Asymmetry

\section{Panel E: Utilities}
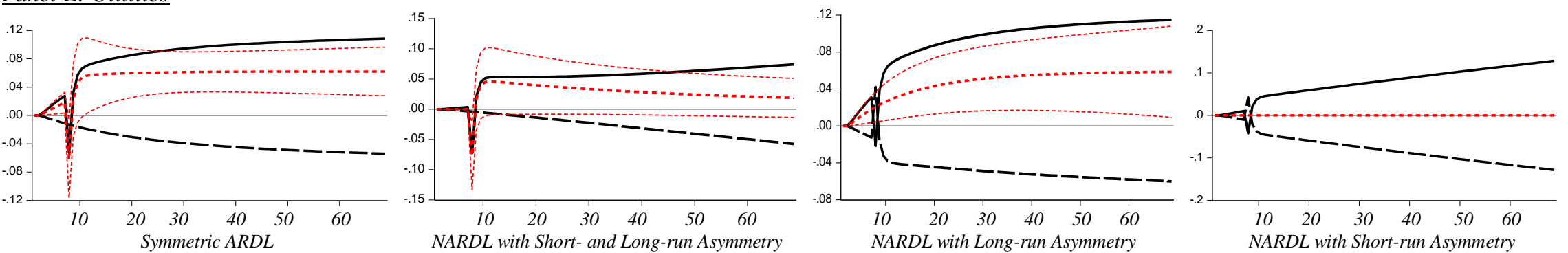

\section{Panel F: Materials}
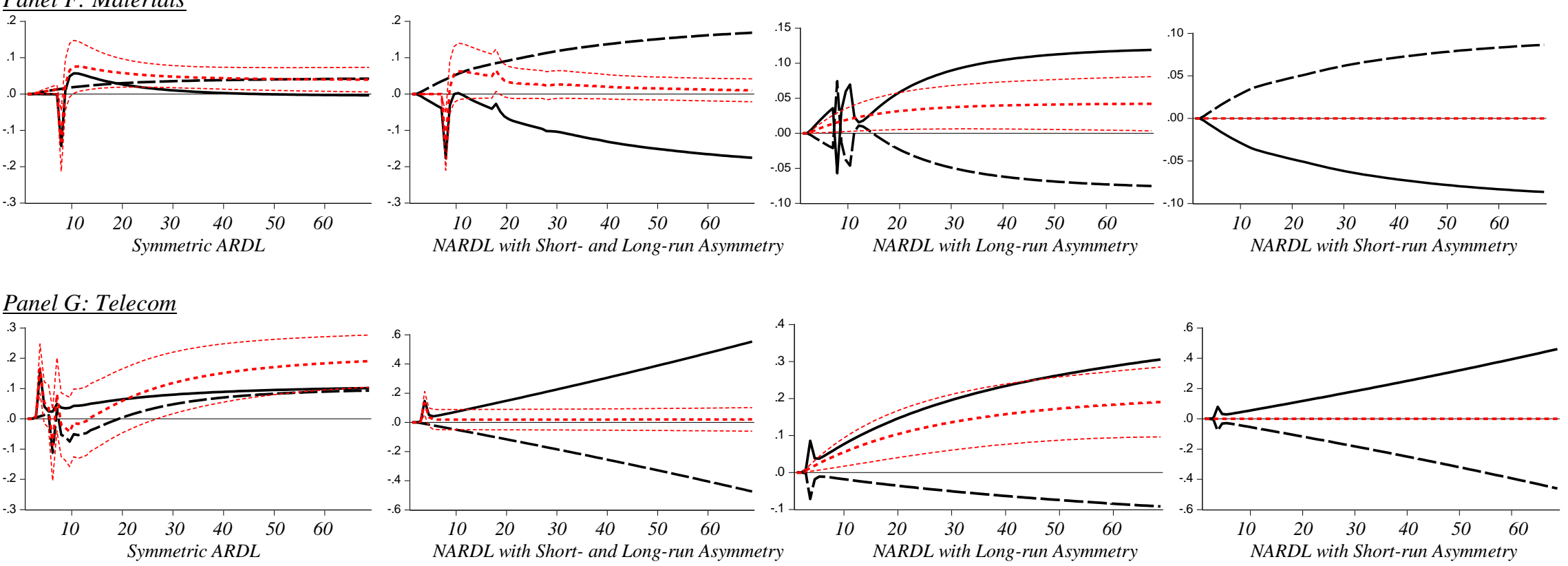

Panel H: Industrials 

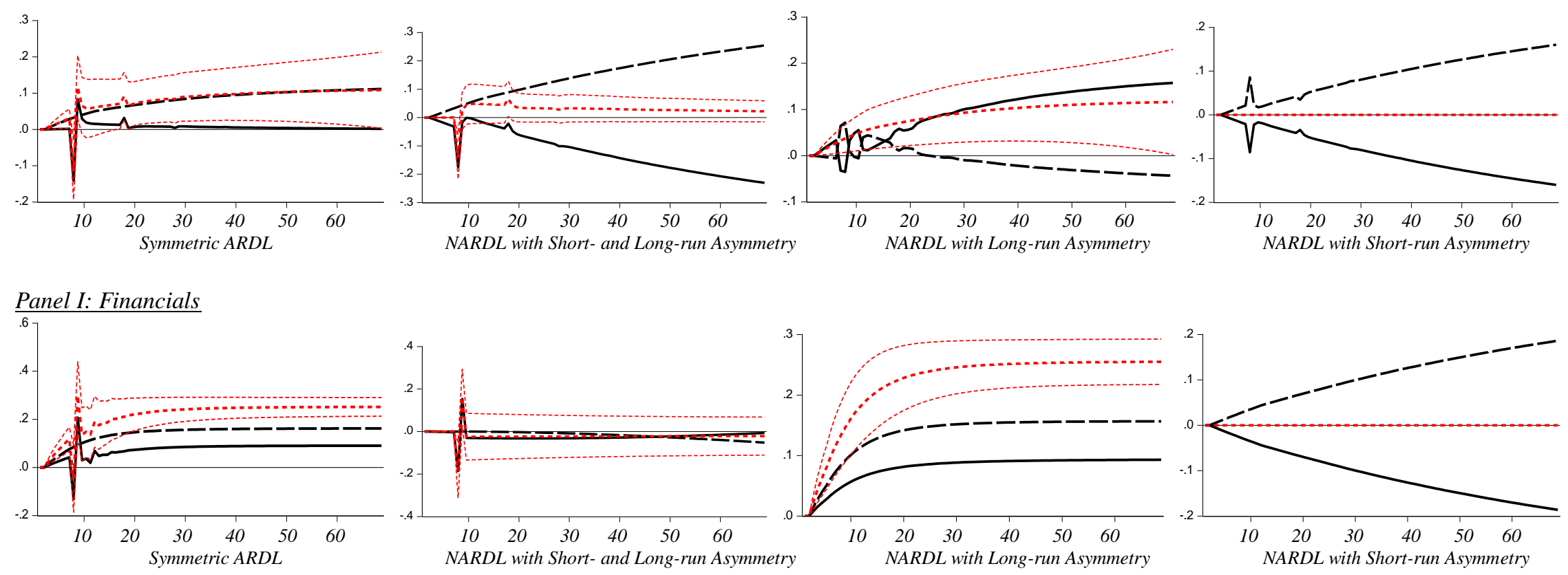

Figure 3: NARDL estimations pattern 


\section{Appendix:}

Table A1: Models on Economic Policy Uncertainty

Studies

Country

Methodology

Antonakakis et al, 2013

US

US

VAR

US, Brazil, Russia,

Mensi et al, 2014

India, China \& South

Africa

19 Emerging Markets

Donadelli \&

of Asia, East Europe

Persha, 2014

\& Latin America
Quantile Regression

Approach

\author{
Rolling-Window \& \\ DCC-GARCH
}

Findings/Results

Dynamic correlation between policy uncertainty and stock market returns is consistently negative over time, apart from the latest financial crisis. Increase in policy uncertainty dampens stock market returns,

Economic policy uncertainty accounts for $19 \%$ of the long-term variability in real stock returns. With regard to different industries it is found a rise in policy uncertainty depresses returns in oil sector over extended periods, depresses returns in the short-term in the auto and retail sectors, and depresses returns in the long-term in the gold sector.

Global stock market (GSM) has appositive \& significant impact on the BRICS stock market returns before and since the onset of the current global financial crisis. BRICS stock markets co-move with the GSM in bullish markets, while they are independent when the market is bearish.

Negative correlation was observed between industrial stock market excess returns and global economic policy uncertainty, suggesting that a higher economic policy uncertainty lowers stock prices.

\begin{tabular}{lcc}
$\begin{array}{l}\text { Lean and Nguyen, } \\
2014\end{array}$ & $\begin{array}{c}\text { Asia Pacific, Europe } \\
\text { \&North America }\end{array}$ & $\begin{array}{c}\text { GARCH, IGARCH, } \\
\text { EGARCH \& TGARCH }\end{array}$ \\
\hline Arouri et al., 2014 & $\begin{array}{c}\text { US, Europe, China } \\
\text { and Gulf }\end{array}$ & $\begin{array}{c}\text { Correlation \& Panel } \\
\text { regression }\end{array}$ \\
\hline $\begin{array}{l}\text { Brogaard \& } \\
\text { Detzel, 2015 }\end{array}$ & US & $\begin{array}{c}\text { OLS Regression \& } \\
\text { Correlation }\end{array}$ \\
\hline Chang et al., 2015 & OECD & $\begin{array}{c}\text { Bootstrap Panel } \\
\text { Causality Test }\end{array}$ \\
\hline Bekiros et al., & & Nonparametric Granger \\
2016 & US & Causality Test \\
\hline
\end{tabular}

US policy uncertainty only affects returns in two regions (Asia Pacific and North America) during the crisis period.

An increase in EPU affects negatively stock returns and has also delayed the positive effect on volatility.

economic policy uncertainty increases by $1 \%$, contemporaneous market returns fall by $2.9 \%$ and market volatility increases by $18 \%$

Out of 7 countries political uncertainty affects stock prices in only two (Italy \& Spain) countries. However, casualty is from stock price PU for US and UK markets.

EP can predict the stock returns, EPU cannot predict stock returns in shorter sub sample, however, cause real stock returns on a large sample. EPU can also predict the volatility in stock returns.

Wu et al., $2016 \quad 9$ including US

Bootstrap Panel Granger

Stock market not always react negative to change in EP; EPU lead stock Causality market in UK, however, stock market lead EPU in India, Italy and Spain but no relationship was reported for Canada, China, Germany, US and France.

\section{Dakhlaoui and}

Aloui, 2016
Antonakakis et al., 2016
US, Brazil, Russia,

India, China \& South

Africa
GARCH, EGARCH,

TGARCH, TSGARCH, PGARCH
There is a time varying correlation between US EPU and stock market returns of Brazil, Russia, India, China \& South Africa. US EPU index can also predict the volatility of stock market up to certain extent. 


\section{Arouri and}

Roubaud, 2016

Gao \& Zhang,

2016

Li et al., 2016

China \& India
US, China \& India

Regression

Correlation

Bootstrap rolling

window approach

In US EPU have strong and persistent effect on stock return and volatility, in India this impact is not strong, however, in china there is no impact of EPU on return \& volatility.

High correlation between gold market and stock market is observed in the period of low EPU and vice versa.

Increase in EPU negatively impact the stock returns in Indian and Chinese stock market.

Individual stock price of oil and gas sector covary with the fluctuations in

Kang et al., 2017

US

Structural VAR Model

EPU and10\% variation in the stock returns of oil and gas corporation are due to EPU.

EPU is observed for significant negative effect on long term stock and bond correlation.

Relationship of global EPU is checked with crude oil market and industry

Fang et al, 2017

DCC-MIDAS

level stock returns for long run volatility and correlation. Positive

Yu et al. (2018)

US

GARCH-MIDAS \& DCC-MIDAS relationship of EPU is observed for its positive impact on long run correlation of returns and oil prices. 